\title{
Comparative analysis of the food webs of two intertidal mudflats during two seasons using inverse modelling: Aiguillon Cove and Brouage Mudflat, France
}

\author{
Delphine Degré ${ }^{a}, \underline{b}$, Delphine Leguerrier ${ }^{a}$, Eric Armynot du Chatelet ${ }^{\underline{a}, ~} \underline{c}$, Jadwiga Rzeznik ${ }^{a}$, Jean- \\ Christophe Auguet ${ }^{\mathrm{a}}{ }^{\mathrm{a}}$, Christine Dupuy ${ }^{\mathrm{a}}$, Elise Marquis ${ }^{\mathrm{a}}$, Denis Fichet ${ }^{\mathrm{a}}$, Caroline Struski ${ }^{\mathrm{a}}$, Emmanuel \\ Joyeux ${ }^{\underline{b}}$, Pierre-Guy Sauriau ${ }^{\underline{a}}$ and Nathalie Niquil ${ }^{\underline{a}}$.
}

${ }^{a}$ Centre de Recherche sur les Ecosystèmes Littoraux Anthropisés (CRELA, UMR 6217 CNRS-IFREMER-

Université de La Rochelle), Pôle Sciences et Technologie, Av Michel Crépeau, 17042 La Rochelle Cedex, France ${ }^{\mathrm{b}}$ Réserve Naturelle de la Baie de l'Aiguillon, ONCFS-LPO, Ferme de la Prée Mizottière, 85450 Sainte-Radegonde des Noyers, France

'Université d'Angers, UPRES EA 2644, Faculté des Sciences, 2 Bd Lavoisier, 49045 Angers Cedex, France

*: Corresponding author : nniquil@univ-Ir.fr

\begin{abstract}
:
Inverse analysis was used to model the food webs of two intertidal mudflat ecosystems: Aiguillon Cove (AC) and Brouage Mudflat (BM) (south-western Atlantic coast, France). The aim of the present study is to describe and compare the functioning of these two ecosystems. The method of inverse analysis has been adapted in order to take into account, in a single calculation, two seasons: spring/summer (mid-March to mid-October) and autumn/winter (the rest of the year). Gathering all available data on the two sites, the most important gaps in knowledge were identified with the help of sensitivity analyses: they concerned mainly the exports of material by grazing fish (such as mullet Liza ramada), resuspension of microphytobenthos, and fluxes linked to microfauna which is poorly known for the two systems. The two sites presented the same overall type of functioning (net import of detritus, export of living organic material and higher faunal activity during spring/summer). In both ecosystems, primary production was dominated by the microphytobenthic production, of which a great part was exported via water-column advection and biotic vectors (grazing fish), while many secondary producers also used detritus as a food resource. Each system also had its own characteristics, one BM being much more seasonally driven than the other AC. It appeared essential to take the seasons into account, as variations in microphytobenthos production and in meiofauna, macrofauna and biotic vectors led to great differences in the food-web organisation

Résumé
\end{abstract}

Keywords: food web; steady-state; inverse analysis; tidal flat; sensitivity analysis; Atlantic coast 


\section{Introduction}

European intertidal mudflats are considered as amongst the most biologically productive areas in the world (McLusky, 1989). Along the French Atlantic coast, Aiguillon Cove and Brouage Mudflat are known both for their shellfish culture (Goulletquer and Héral, 1997; Goulletquer and Le Moine, 2002), their role of nursery for juvenile fish within the Bay of Biscay (Le Pape et al., 2003 a,b), and feeding ground for shorebirds (Triplet et al., 2001). Each of those two areas is composed mainly of intertidal mudflats (Verger, 1968; Gouleau et al., 2000). The purpose of the present paper is to describe and compare the functioning of these two close intertidal areas, addressing questions about their similarities and differences and about their seasonal dynamics.

In coastal management, it is necessary to describe holistically the ecosystem functioning (Jørgensen and Müller, 2000a). A good way to gather all the information on an ecosystem's biocenosis and assess the relationships between its various components is to build its food-web model (Winemiller and Polis, 1996). Inverse analysis (Vézina and Platt, 1988) allows complete food-web models to be constructed from ecological data too sparse to allow other means. However these models generally describe balanced food webs and all temporal variations are erased by an annual average. This is a drawback for European mudflats, which vary seasonally. The wintering season, when migratory shorebirds are the more numerous (Yésou, 1992), is characterised by lower primary production (Cariou-Le Gall and Blanchard, 1995; Blanchard et al., 1997; Guarini et al., 1998) and reduced secondary production (Bachelet, 1982; Essink et al., 1991). One way to represent such seasonal changes is to model separately the mean food web of each season, and then compare the functioning of the two periods (Baird and Ulanowicz, 1989; Donali et al., 1999). The problem of such a method is that the seasons are totally independent one from the other, and it is necessary to allow variation of the different compartments' biomass between the two seasons, even though the system will be at steady-state at the annual scale. Computing one season with a possible imbalance and then using it to constrain the other is not a satisfying solution either, because then, the computation of the first season takes the lead over the second one. It was thus decided to compute both seasons by a simultaneous calculation. Inverse analysis was adapted to take into account two seasons in an annual-balanced model which would include all the current knowledge about the two sites. The classical matrix calculation (Vézina, 1989) was modified by coupling matrices bearing information on the two seasons or general information. This inverse-analysis modelling allows 1- evaluation of fluxes between the trophic components about which there exists the least information, 2- investigation of which relationships between the trophic components are dominant and 3- demonstration, with the help of sensitivity analyses, of those components which are needed to improve our knowledge.

These two mudflats have not been studied with the same intensity during the past years from a species richness point of view (de Montaudouin and Sauriau, 2000) and only the trophic food web of the Brouage Mudflat has been modelled by Leguerrier et al. (2003, 2004). We propose here to go further in the comparison of the functioning of both intertidal areas by using more recent data obtained in the field and by improving the modelling method. Aiguillon Cove has never been the subject of a model and has been studied only for a shorter time but many data can be acquired today on its population densities and dynamics, from primary producers to top predators. 


\section{Materials and methods}

\subsection{Study sites and sampling}

Located on the south-western Atlantic coast of France, the Charentais Sounds (Pertuis) are situated between the latitude $\mathrm{N} 45^{\circ} 50^{\prime}$ and $\mathrm{N} 46^{\circ} 20^{\prime}$ and the longitude $\mathrm{W} 1^{\circ} 00^{\prime}$ and $\mathrm{W} 1^{\circ} 30^{\prime}$ (Figure 1). The Brouage Mudflat (BM) and the Aiguillon Cove (AC) are protected from the direct ocean influence by Ile d'Oléron and Ile de Ré, respectively and influenced by estuarine transport through the Charente and Sèvre Niortaise rivers. These extended mudflats are similar to semi-enclosed macrotidal bays (Verger, 1968) and both of them are important international areas for wintering shorebirds (Joyeux, 2001).

[Figure 1]

\subsubsection{Brouage Mudflat}

The Marennes-Oléron Bay is situated east to the Oléron Island and west to the mainland (Figure 1). It covers $180 \mathrm{~km}^{2}$ of which $60 \mathrm{~km}^{2}$ are constituted of mudflats. The most extended flat is the Brouage Mudflat (BM), situated in the eastern part of the bay that covers $40 \mathrm{~km}^{2}$ (Gouleau et al., 2000). It has a relatively flat bottom slope (1:1000) and a very large tidal area (4.5 km wide) of which the middle part is covered with prominent bedforms described as 'ridges and runnels' (Gouleau et al., 2000). Current speeds can vary from 0.2 to $0.6 \mathrm{~m} . \mathrm{s}^{-1}$ (Bassoulet et al., 2000; Le Hir et al., 2000) but maximum current speeds may reach $1.2 \mathrm{~m} . \mathrm{s}^{-1}$ in spring tide (SHOM, 2001). Half of the lower part of the intertidal zone is covered by oysters from abandoned oyster parks; the other half is still being used for oyster culture. Here, was represented a mean square meter composed of $84 \%$ of "free" mudflat, and $16 \%$ covered with exploited oyster racks, which is the amount encountered for the whole bay (Lemoine, pers. comm.).

Both fauna and flora benthic communities from BM have been characterised (Sauriau et al., 1989, Cariou-Le Gall and Blanchard, 1995), and numerous data are available on its benthic ecology (see details in Leguerrier et al., 2003, 2004). The abundance of foraminifera was evaluated in March, June, October 2003 and February 2004, for 3 stations. The density of meiofauna (mainly nematodes) was also assessed at 3 stations, in April, July, October 2000 and January 2001 (Rzeznik-Orignac et al., 2003). The observation of their morphology (RzeznikOrignac et al., 2003) gave indices of their food regime during the two seasons according to the classification of Wieser (1953 in Rzeznik-Orignac et al., 2003). Population dynamics properties of the two main macrobenthic species, i.e. Scrobicularia plana and Hydrobia ulvae, were also estimated from month-to-month surveys (Degré et al., 2003; Hautbois et al., 2002).

Knowing the concentrations of material in the Marennes-Oléron Bay (phytoplankton and POC: RAZLEC database, sampled every two weeks: Soletchnik et al., 1998) (Table 1), it was possible to assess the inputs to the system from the Marennes-Oléron Bay (Table 2). Measures on the water column above the intertidal mudflat of Brouage are scarce. The pelagic bacteria counting permitted an evaluation of pelagic bacterial export during this season. For this, water samples were collected monthly at the ebb cycle of spring tide from April 2002 to April 2003. As no information was available for microzooplankton and to avoid letting free its exchanges by transport, a value of biomass from April 2002 in the close Loire plume, in the Bay of Biscay (Marquis, unpub. data) was taken into account. 


\subsubsection{Aiguillon Cove}

The Aiguillon Cove (AC) is a large wadden (Verger, 1968) of $49 \mathrm{~km}^{2}$, of which $33 \mathrm{~km}^{2}$ are constituted of mudflats and $11 \mathrm{~km}^{2}$ of surrounding salt-marshes. Those salt-marshes and the neighbouring agricultural areas of the Marais Poitevin are drained by a dense network of small channels, which import freshwater in the cove in addition to the Sèvre Niortaise River (Figure 1). The cove is a semi-circular sedimentation basin for silts and clays, which are mainly trapped in its landwards parts (Verger, 1968). It has a gentler bottom slope and a larger mudflat on the southern than on the northern part (1.5:1000 vs. 1.8:1000 and 3.5 vs. $3 \mathrm{~km}$ respectively). The Aiguillon Cove receives oceanic inputs via the Pertuis Breton too. Current speeds averaged 0.2 to $0.6 \mathrm{~m} . \mathrm{s}^{-1}$ but maximum current speeds may reach $1.3 \mathrm{~m} . \mathrm{s}^{-1}$ over the mudflat in spring tide (SHOM, 2001).

Two systematic sampling surveys of 91 regularly spaced stations were performed during a week in March and October 2002 but only data from intertidal stations were used as carbon biomass information for the trophic food web model (Table 1). At each station, two sediment grab samples (Smith-McIntyre grab of $0.1 \mathrm{~m}^{2}$ ) were sieved through a $1 \mathrm{~mm}$ mesh. The retained macrofauna were fixed and stored in buffered formalin/seawater solution (4\%) for determination and weighing (ash-free dry weight measured after $48 \mathrm{~h}$ drying at $50^{\circ} \mathrm{C}$ and $4 \mathrm{~h}$ ignition at $\left.450^{\circ} \mathrm{C}\right)$. Sediment cores $\left(0.0025 \mathrm{~m}^{2}\right)$ were also sampled during each week of systematic sampling in March and October 2002. First, the concentration of Chlorophyll $a$ in the first centimetre of those mud cores was measured. Second, the abundance of meio- and microfauna, especially nematodes and foraminifera, was estimated, following analytical protocols previously given by Rzeznik-Orignac et al. (2003) and Armynot du Chatelet et al. (2005).

The population dynamics of the "bivalves"' compartment were also studied each month at two stations from January 2002 to April 2003 in order to evaluate the secondary production and elimination in this largest macrobenthic compartment in AC. Import and export fluxes were calculated by multiplying Chlorophyll $a$ concentrations in the Breton Sound (bimonthly results from the REPHY database: Gailhard et al., 2002) or in the Sèvre Niortaise River (Direction Départementale de l'Environnement-Vendée, Cellule Qualité Environnement Littoral database) by estimates of tidal movement or the Sèvre output following the hydrodynamical model used for BM. Finally, consumption by shorebirds was evaluated on the basis of Wolff et al.'s (1975) equation and the monthly counting in AC by the managers of the Nature Reserve.

Use of geographical information system (GIS, ArcView 2.0) together with quantitative information on shellfisheries (Goulletquer and Lemoine, 2002) allowed us to represent a mean square meter composed of $97 \%$ of "free” mudflat, $2 \%$ of "mussel culture" and $1 \%$ of oyster racks.

\subsection{Inverse analysis}

\subsubsection{The method of inverse analysis}

Inverse methods have been developed to solve the problem of the lack of available data when modelling various systems (Parker, 1994). In food-web modelling, the number of estimated parameters is generally far less than the number of not estimated parameters. Inverse analysis, as developed in ecosystem modelling by Vézina and Platt (1988), seeks to include all existing knowledge about a system in order to achieve the best estimates of food-web fluxes. The method requires that both the compartments and the possible fluxes linking them are defined in an a priori or conceptual model. This model defines the flows as the unknowns of our system. They are written as a vector called $r$. 
Mass-balance rules are translated into linear equations between fluxes so that the system is in steady state. All available data from precise local measurements in the ecosystem are used to build a system of linear equations on the fluxes. The system of equations (mass balance and local information) is written:

$\mathrm{A} * \mathrm{r}=\mathrm{b}$

where $\mathrm{A}$ is a matrix of coefficients and $\mathrm{b}$ contains the solution vector of the equalities.

Then less precise information, mainly data from similar sites and from laboratory experiments, lead to the building of linear inequalities concerning flows or physiological rates. The system of inequalities is written:

$\mathrm{G} * \mathrm{r} \geq \mathrm{h}$

where $\mathrm{G}$ is a matrix of coefficients and $\mathrm{h}$ is the boundaries vector of inequalities.

Application of these constraints reduces the space for possible solutions but does not result in a unique solution. In order to select one solution (the solution vector), the least-square criterion is applied, i.e. the solution is that with the smallest Euclidian norm.

\subsubsection{Coupling two seasons}

The idea developed here was to couple the computation of the two seasonal food webs in the same calculation. The algorithm of the calculation remains the same as in Vézina and Platt 1988, but our new method proposes another way to build the different vectors and matrices. The new vector of unknowns, that will be named $F$ hereafter, is composed of the two vectors $F_{1}$ and $F_{2}$, which contain the flows of the two seasons (written as transposed vectors $F_{1}^{\prime}$ and $F_{2}^{\prime}$ in Figure 2). The mass balance equations are established for the whole year and determine a first set of equations (matrix of coefficients is $A_{e}$ and right hand terms in $b_{e}$ ). Another set of equations is built for each season and determines two matrices of coefficients: $A_{1}, A_{2}$ and two right hand vectors: $b_{1}$ and $b_{2}$. Then a set of equations concerns annual information, for data determined two generally to have the seasonal variation, and defines the matrix $A_{g}$ and the vector $b_{g}$. All these matrices are assembled as shown in figure 2 , which allows defining an equation:

$\mathrm{A} * \mathrm{~F}=\mathrm{b}$

where $A$ is the association of $A_{e}, A_{1}, A_{2}$ and $A_{g}$ as in figure 2 and $b$ is an association of $b_{e}, b_{1}, b_{2}$ and $b_{\mathrm{g}}$.

The inequalities are defined for the two seasons, which allows the building of matrices $G_{1}$ and $G_{2}$ of coefficients, and the boundaries vectors $h_{1}$ and $h_{2}$. Some inequalities apply on an annual basis, which defines the matrix $G_{g}$ of coefficients and the vector $h_{g}$ of boundaries. These matrices and vectors are associated as shown in figure 2 and define the set of inequalities:

$\mathrm{G} * \mathrm{~F} \geq \mathrm{h}$

where $G$ is the association of $G_{1}, G_{2}$ and $G_{g}$ as in figure 2 and $h$ is an association of $h_{1}, h_{2}$ and $h_{g}$.

The resolution of (3) and (4) is done using the same algorithm as in Vézina and Platt (1988).

[Figure 2] 


\subsection{Integration of knowledge}

\subsubsection{The conceptual models}

The conceptual (also called a priori) models were constructed on the bases on the knowledge described above. The two chosen seasons were: 1) "summer": from March $15^{\text {th }}$ to October $14^{\text {th }}$ and 2) "winter": from October $15^{\text {th }}$ to March $14^{\text {th }}$. Hence, there was one season of 7 months and the other one of 5 months. This partition has been chosen to take into account the ecological parameters which are: 1 ) the wintering of migratory birds (which arrive in October and have all left in March); 2) the gastropoda which were more precisely studied (Hydrobia ulvae, Haubois et al., 2002, 2004), begin to reproduce in March; 3) the nematodes, which are more numerous in winter (Rzeznik-Orignac et al., 2003); and 4) the microphytobenthos which usually begins its high production in March (Guarini et al., 1998; Haubois et al., 2003).

The presented models counted each 16 equivalent compartments (compartments Table 1 and a priori fluxes Figure 3), which were: the benthic and pelagic primary producers (microphytobenthos on the sediment and, in the water column, 'real' phytoplankton and resuspended microphytobenthos), the benthic foraminifers, nematodes, bivalves (mainly Scrobicularia plana, Macoma balthica), annelids (mainly Hediste diversicolor, Neanthes succinea and Nephtys hombergii), gastropods (mainly Hydrobia ulvae), arthropods, shellfish culture (Crassostrea gigas and Mytilus edulis for AC, and C. gigas for BM), pelagic microzooplankton (ciliates and flagellates), mesozooplankton (mainly copepods), fish juveniles (mainly carnivorous fishes, especially juvenile flat fish Solea solea), adult grazing fish (mainly mullet Liza ramada), and shorebirds (mainly Dunlins Calidris alpina, Knot Calidris canutus and black-tailed Godwit Limosa limosa), and benthic and pelagic detritus, which also include the free and attached bacteria. The 106 a priori fluxes between those compartments have been determined on the basis of current biological knowledge. The knowledge on BM being more complete, the conceptual models were slightly different: for the computation, the BM detritus compartments were divided into dissolved organic carbon (DOC), particulate organic carbon (POC) and bacteria.

[Table 1] [Figure 3]

\subsubsection{Translation of data as equations and inequalities}

Estimations realised locally, on the two sites, were translated into equations and inequalities between fluxes of the conceptual model. All the data used for the computations were those used previously by Leguerrier et al. (2003, 2004). Table 2 and 3 contains the complements. Inequalities limiting biomass temporal variations were imposed (equal to the compartments biomass when not known). They concerned one season only, as equalities on the annual equilibrium were added and implied a null total variation.

The input and output flows of plankton and detritus by hydrodynamic transportation (Table 2) were estimated using simple physical equations. A 1D model was developed to compute tidal currents across Brouage mudflat. Following Roberts et al. (2000), who applied a similar model to explore the mudflat morphodynamics. It only considered the conservation of mass and accounts for the water inflow and outflow due to tidal elevation. The use of a 2D model and measurement of current velocity on Brouage mudflat proved that the major component was cross-shore (Le Hir et al., 2000; Bassoullet et al., 2000). Boundary conditions were provided by tidal harmonics (Service Hydrographique de la Marine Nationale, SHOM) and bed elevation was derived from bathymetric charts. The model was applied to compute the 
average tidal exchange along the mudflats and the results were used to calculate the volume and the water exchange at the limit of the food web model.

[Table 2]

The net primary production (NPP) computed for the microphytobenthos was based on observations of the biomass changes during day-time emersion (Blanchard et al., 1998, 2002), and hence was assumed to be the Gross Primary Production (GPP) less respiration, grazing, natural mortality and ER (extracellular release) during this period (Guarini et al., 2000; Blanchard et al., 2001). The gastropod compartment, mainly Hydrobia ulvae, was supposed to accomplish $50 \%$ of its grazing during day-time emersion (because they were more likely to graze on the biofilm (Haubois et al., 2005), and that 25\% of the other fluxes occurred during this period. Hence, the equation of NPP for microphytobenthos is (using the abbreviations given in Table 1 and the convention source $\rightarrow$ sink):

$\mathrm{NPP}=1 \mathrm{gC} \cdot \mathrm{m}^{-2} \cdot \mathrm{d}^{-1}=\mathrm{GPP}-50 \% \cdot($ bphy $\rightarrow$ bgas $)-25 \% \cdot$ bphy $\rightarrow$ (other living compartments + bdet + Resp).

The value of $1 \mathrm{gC} \cdot \mathrm{m}^{-2} \cdot \mathrm{d}^{-1}$ is a mean computed for the whole year and it was supposed to vary from $1.1 \mathrm{gC} . \mathrm{m}^{-2} \cdot \mathrm{d}^{-1}$ in summer to $0.9 \mathrm{gC} \cdot \mathrm{m}^{-2} \cdot \mathrm{d}^{-1}$ in winter, respectively (Guarini pers. comm.).

The net primary production estimation for the phytoplankton varied between the two sites. In Brouage (Table 2), a physics-biology coupled model of primary production allowed a precise estimation of the mean seasonal value (Struski and Bacher in press). In Aiguillon Cove, as such estimation was missing; inequalities were estimated to give a range of realistic values (Table 3). This estimation used a ratio production / biomass from the English Channel (Menesguen et Hoch, 1997) and local values of phytoplankton biomass (data from REPHY network, Gailhard et al., 2002).

[Table 3]

Inequalities were set to give a range of realistic values for the diets of macrofauna compartments. The largest ranges of proportions for each diet cited in the literature were used, to take into account the spatial, inter-annual and seasonal variability. For example, the annelids diet was estimated by averaging the diet composition of the three main species: Hediste diversicolor ([50-100 \%] carnivory included majority of nematodes, and minority of annelids, bivalves, arthropods, or mesozooplancton, and [30-50\%] detritivory included detritus and bacteria), Neanthes succinea ([50-100 \%] benthic herbivory and [30-50 \%] benthic detritivory) and Nephtys hombergii ([50-100 \%] annelid carnivory, [30-50\%] benthic herbivory and [30-50 \%] benthic detritivory). For bivalves, the diet composition range were set to [30-70 \%] of benthic herbivory and [30-70 \%] of pelagic herbivory. For arthropods, the ranges were [50-100 $\%$ ] for benthic detritivory and [20-70 \%] for benthic carnivory on total macrofauna.

\subsection{Activity of compartments}

The activity of each compartment was defined here as its entering Throughput. The Throughput of a compartment is defined as the sum of its entering or exiting flows, which are equal in the case of a steady-state system (Ulanowicz, 1986): as each season was unbalanced, and as our focus was on trophic exchanges, the activity of a compartment was defined as the sum of all biological inflow (excluding the physical ones). The detritus Activity was defined as the bacterial activity, i.e. the flux from the detritus compartment to itself. Hence this counted in the 
meantime the bacterial uptake, the DOC release and the mortality by viral lysis (which is the main mortality cause), and the transformation of POC into DOC by bacterial action.

\subsection{Sensitivity analyses}

The sensitivity analyses were conducted with a double purpose: to assess the robustness of the result towards variations in the data, and to identify the effects of variations in the most sensitive data (Saltelli et al., 2000). These variations can be due to uncertainties or inter-annual variability of the data. The principle is to make the data element vary one by one and compute the corresponding new inverse analysis result (Jackson and Eldridge, 1992; Niquil et al., 1998; Vézina and Savenkoff, 1999). The method applied consisted in replacing all the equations by inequalities (boundaries being the limits of the confidence interval of the concerned parameters), and on imposing one equation: the one concerning the parameter tested. Then the inverse analysis solution to the new system was computed for various values of the parameter ( 5 from its reference value to its lowest, 5 from the reference to the highest), and for each tested parameter. This way, it was possible to test the influence of: total inputs, primary productions and resuspension of microphytobenthos, production by bivalves, grazing by gastropods and fish on microphytobenthos, and consumption by juvenile nekton and birds. A value for the resuspension of microphytobenthos was imposed by an annual equation, and it was varied between 0 and $100 \%$ of the net primary production. To test the grazing-fish consumption in $\mathrm{AC}$, an equation was added and its result was varied between 0 and the value observed in the result of the computation. In all other cases, all the values were varied within the confidence interval of the constraints.

As input parameters were set to different ranges of values, it was necessary to create a homogeneous index to compare the effect of each parameter variation on each resulting flux. The relative variation in the resulting flux, normalized by the relative variation of the parameter, was computed. This was called the Sensitivity Index, SI. In the computation of those relative variations, the reference taken was the result obtained for the middle value of the datum (which was the one taken to build the corresponding equation in the food web model). Hence, the computation of the index is the following:

$$
\mathrm{SI}(\mathrm{P}, \mathrm{R})=\left\langle\frac{\frac{\mathrm{R}(\mathrm{s})-\mathrm{R}_{\text {ref }}}{\mathrm{R}_{\text {ref }}}}{\frac{\mathrm{P}(\mathrm{s})-\mathrm{P}_{\text {ref }}}{\mathrm{P}_{\text {ref }}}}\right\rangle_{\mathrm{s}}
$$

where "P" stands for "tested parameter", "R" for "resulting flux", "ref" for "reference model" and "s" for "simulation variation number". For each parameter and each resulting flux, the SI was the mean obtained over all simulations, which is symbolized by $<>_{s}$. This index corresponds to the ratio of the relative variation of the result to the relative variation of the parameter.

Considering that the computation of a "global tuning importance" of a parameter on more than one variable is equal to the sum of all "tuning importance" of this parameter to each of the variables (Solidoro et al., 2003), the sum of SI over all results $\mathrm{R}$ for one parameter $\mathrm{P}$ was computed. This index $S I(P)$ gave the overall influence of this parameter on the results: $\mathrm{SI}(\mathrm{P})=\sum_{\mathrm{R}} \mathrm{SI}(\mathrm{P}, \mathrm{R})$. The same principle can be applied for the computation of the global impact on one result: $\mathrm{SI}(\mathrm{R})=\sum_{\mathrm{P}} \mathrm{SI}(\mathrm{P}, \mathrm{R})$ 
To complete this sensitivity analysis, another simulation was realised (results not presented here). The Brouage Mudflat model was re-estimated with a limited number of equations and inequalities, by suppressing all information not documented in Aiguillon Cove. This way, it was possible to check that the differences that were enlightened between the two ecosystems were kept, in tendency, when we use the same quantity of information.

\section{Results}

To enable comparison between the functioning of the two seasons, flux values (Tables 4 and 5) are given in gC. $\mathrm{m}^{-2} \cdot \mathrm{month}^{-1}$, i.e. the results of inverse analysis, calculated by season, were divided by 7 for the summer season and by 5 for the winter season.

[Table 4] [Table 5]

\subsection{Null fluxes}

All the fluxes of the a priori model being considered as probable fluxes, the estimation of null values indicates the poorly documented flows.

During summer, 33 fluxes were set to zero in the AC model, 25 in the BM model. During winter, 35 fluxes were set to zero in the AC model, 29 in the BM model. This is partly due to the fact that the BM model is more documented than the AC model and that the summer season is more documented than the winter season, for both sites. Almost all the null flows in summer were also null in winter. Indeed, most of the processed were better studied in warm than cold season.

The most concerned compartments, either as a source or a sink for these null flows, were the zooplankton (pmes) and especially the microzooplankton (pmic). Non-null ingestion flows of microzooplankton collapsed from summer to winter, as it had no activity during winter in either of the two models.

The other null values concerned several consumers (bivalves, annelids, arthropods, cultivated molluscs, juvenile fish and mullets). When no information was available on the quantitative diet of the consumer compartments, the availability of food sources concentrated the ingestion on a limited number among all the possible ingestion fluxes.

\subsection{Activities}

The most active compartments for the two systems were the two detritus compartments (benthic for BM, pelagic for AC) (Figure 4). The most active living compartment was the microphytobenthos in all cases but one: the BM model in winter, were the cultivated oysters were more active. Nematodes were the next most active compartment for BM. In AC, they were also active but less than mullets during both seasons, and than bivalves during summer. The exportation by mullets equals $30 \%$ of their activity, thus representing a high value in AC (7 and 6 gC. $\mathrm{m}^{-2}$.month ${ }^{-1}$ for summer and winter, respectively). The bivalves and foraminifers had similarly high activity values among benthic animals. The shellfish culture had a greater activity in BM than in AC, while it was the contrary for the grazing fish. The other activities were of the same order of magnitude in the two systems. 
The differences of compartment activities between the two seasons were in most cases a decrease in activity from summer to winter. Only 11 fluxes were more important in winter than in summer for AC model, and 28 for BM model. Those fluxes concerned in particular the shorebirds' activity in both systems (which was higher by $139 \%$ in AC and 198\% in BM), the shellfish culture activity in both systems (+ 19\% and $+218 \%$ in AC and BM respectively), and, in BM only, the nematodes and benthic detritus activity (raises of $25 \%$ and $7 \%$ were observed, respectively). The activities of shorebirds, despite their marked increase from summer to winter, were the smallest ones in both systems.

The sum of all flows (Table 6) was the highest for BM during winter, followed by BM during summer, then AC in summer and AC in winter. The greatest part corresponded to physical flows, especially imports and exports of detritus. Concerning the biological flows between compartments in the benthos, BM presented more activity than AC, and summer than winter, for both systems.

[Table 6]

\subsection{Seasonal changes in the diets}

The seasonal changes not only affected the compartment activity, but also concerned the diet of some animal compartments (Table 5). The diet of nekton juveniles, for example, was exclusively based on bivalves in AC, but, in BM, the consumption on arthropods during summer was reported on bivalves during winter. The grazing fish, which kept a roughly equilibrated diet between microphytobenthos and detritus in AC, changed their exclusively herbivorous diet during summer to prey on nematofauna during winter in BM. They can enter then into competition with annelids, which transferred $20 \%$ of their diet to the nematodes instead of on other annelids ("cannibalism"). Overall, the diets were more concentrated on detritus than autotrophs in all the 4 situations. The detritivory/ herbivory ratio was higher in winter than in summer (Table 6). This seasonal difference was less marked than the inter-site difference, BM having the highest ratios for the two seasons.

\subsection{Net export from the two systems}

Over a complete year, the systems being in equilibrium, the overall import (physical imports + gross primary production) were equal to the overall export (physical exports + burial + respiration). Yet, slight differences appeared within each season (Figure 5): the two systems tended to show overall net import of material during summer and overall net export during winter. However, a net physical import of material from the water column must be noted for the two sites and during the two seasons. The quality of this material is shown in the figure 5: in proportion, the exports were enriched in living material when compared to the imports. In absolute values, the export of living material (phyto- and zooplankton) was greater than the import for AC during summer (living export: 33.7 vs. import: 23 gC. $\mathrm{m}^{-2} . \mathrm{month}^{-1}$ ), and for BM during both seasons (35.2 vs. 34.4 and 17 vs. 16 gC.m ${ }^{-2}$.month ${ }^{-1}$ during summer and winter respectively).

[Figure 5]

\subsection{Sensitivity analyses}

In both systems, bivalves' production greatly influenced the results (Figure 6). In AC, the oceanic inputs were the most influential parameter. During both seasons, their value was 
positively correlated with all the fluxes linked to detritus. In BM the most influential parameter was the shellfish culture. The difference between the influence of total shellfish data and the one of production alone represented the influence of respiration and pseudo-faeces, which is hence as influential as shellfish production alone in relative terms. Net primary production was very influential in the AC system, a little less so in BM, and it had more impact during summer than during winter. Consumption by birds was of very low relative importance in the two systems, and influenced only the diets of juvenile fish. The figure 6 also shows that the resuspension of microphytobenthos is a model output that had a high impact on the computation of other fluxes in the system. It was also a flow value that was very sensitive, being impacted by nearly all the tested parameters in both systems and more in BM than in AC. In all cases, the grazing by mullets had a significant impact on microphytobenthos resuspension, on the annelids' compartment, and on the nematodes' grazing on microphytobenthos.

[Figure 6]

\section{Discussion}

To discuss the results, one needs to keep in mind the various hypotheses and assumptions made to build the steady-state models. Some of the results could be artefacts due to the method itself, in particular in view of the least square solution principle (Vézina, 1989) which, combined with too poorly constrained fluxes, might lead to results open to criticism (Niquil et al., 1998; Leguerrier et al., 2003). Hence, the results concerning the microzooplankton will not be discussed here because it is a mathematical artefact that the consumption in this compartment occurred only during summertime. Indeed, due to a lack of data, this compartment was only annually constrained. Similarly, with diets in compartments too poorly constrained, they reveal only the availability of their prey items (Leguerrier et al., 2004). As any available data were used to build the inverse analysis model, it is not possible to assess directly its validity, and the results must be considered with some caution. However, comparison of our model results with published data allowed us to ascertain whether their order of magnitude was consistent with reality (Chardy and Dauvin, 1992), and sensitivity analyses helped us to identify the most missing data, and thus design forthcoming sets of measurements.

\subsection{Importance of grazing fish}

Grazing fish had an important activity and constituted a privileged export pathway for locally produced microphytobenthos and benthic detritus. But, without any available quantitative data, they were nearly totally unconstrained in the model. Laffaille et al. (2002) measured that mullets exported $8 \%$ of their fresh body weight, during each tide where they can reach the salt marsh creeks of Mont Saint-Michel bay (43\% of the tides). 31\% consisted of organic matter. In the present case, supposing that they feed equally during day and night (Morrison et al., 2002), that would mean a grazing fish concentration of $364 \mathrm{~g}$ fresh weight. $\mathrm{m}^{-2}$ in AC and $78 \mathrm{~g}$ fresh weight. $\mathrm{m}^{-2}$ in BM which is unrealistic (Parlier pers comm.). Hence, it could be useful to assess: (1) the actual mullet densities on each mudflat, (2) their grazing on microphytobenthos over the whole year (the experiments in Brouage were conducted from March to June and extrapolation was made on the basis of general observations).

Qualitatively, the obtained diet of the mullets was dominated by microphytobenthos and/or detritus, is conform to diets studied in other sites (e.g. Bruslé, 1981; Laffaille et al., 2002, Almeida, 2003). 


\subsection{Importance of microphytobenthos resuspension}

As underlined in the sensitivity analysis result, the microphytobenthos resuspension has a high impact on the computation of other fluxes and is also the most influenced flux. Indeed, this flux is simultaneously directly linked to microphytobenthos production and consumption by grazing-fish and nematodes and indirectly to consumption of phytoplankton (shellfish production).

The results show low rates of resuspension compared to NPP, during summer, only 6.3\% and 3.4\% in AC and BM respectively, and high ones during winter, with 30\% and 29\% respectively. This is consistent with the fact that winter is a more perturbed season in terms of meteorological conditions which may increase potential resuspension, and the observation that microphytobenthos contribution to pelagic communities increases from $1 \%$ to $50 \%$ during winter (Guarini et al., 2004).

Considering a biofilm concentration of 1.25 gC.m ${ }^{-2}$ (Guarini et al., 2000), the obtained values represented 1.4 biofilms resuspended per month in summer and 5.2 in winter for AC, and 0.9 and 5.6 in BM. These values are probably underestimated, according to the current conceptualisation of the biofilm functioning in algal dynamics models (Guarini et al., 2000), but further analyses are needed to accurately estimate this flow. Moreover; bioturbation by benthic macrofauna e.g. Hydrobia ulvae (Orvain et al., 2003) and Scrobicularia plana (Orvain, 2005) can also enhance resuspension in general, and resuspension of consolidated biofilm in particular (Orvain et al., 2004).

\subsection{Difficulties in evaluation of macrofauna production}

Macrofauna compartments are preyed upon by shorebirds and fish juveniles. Yet, as the flux from macrofauna to detritus merged faeces and natural mortality, it is difficult to ascertain from the results the exact production value, which included natural mortality. In the literature, most P/B values do not include all the effective production of macrofauna (Bachelet, 1982). Apart for the bivalves, whose population dynamics have been studied on the two mudflats, the effective production of other macrofauna compartments might have been underestimated. Indeed, in the present food-web definition of "production", the elimination term E should be included (Bachelet, 1982). This term might not be a production value for the population itself, but it is transferred to the trophic web. It is not clear what is really taken into account in many of the assessments of $\mathrm{P} / \mathrm{B}$ ratios. Here, the annual averages might have smoothed all small scaled variations and above all the elimination term. Another problem is the variability of $\mathrm{P} / \mathrm{B}$ rates: they may cover a large range of values according to habitat, number of age classes and, above all, relative importance of each cohort (Bachelet, 1982). To avoid the last of these problems, were imposed inequalities on the macrofauna compartment, obtained with the widest possible range of data taken from the literature. As maximal values are reached by the arthropod production in AC and annelids production in BM those results should be clarified in the field.

\subsection{Weak control by top predators}

In each ecosystem, the higher levels (shorebirds and fish juveniles) seemed at first sight to have little or no impact on the ecosystem functioning because their activities were the lowest ones. Yet, they are at the highest trophic level, and hence this index might not be the most revealing one to describe their position in the ecosystem, as advanced by Meire et al. (1994). These authors observed in the Oosterschelde Estuary that even though the roles of birds in the carbon balance of the estuary was rather small, their impact on their population prey may however be important. Even though a comparison to the production might be more accurate, the ratio between bird consumption and macrofauna biomass can be used as an index of predation 
pressure (Meire et al., 1994). The obtained levels were relatively high in BM: $11 \%$ of the macrofauna biomass was preyed upon during summer and $23 \%$ during winter. In AC, the rates were lower: $1 \%$ and $2 \%$ respectively. The BM value (34\% per year) approaches the ones obtained by Meire et al. (1994) in the Oosterschelde Estuary (30 to 37\%). Dierschke et al., (1999a) considered that their obtained value in the southern Baltic Sea (14 to 28\% per year) were low, but that such a predation could locally deplete some populations of the fragmented study area. The main activity of shorebirds on mudflats is their feeding (Burger et al., 1996), and various studies have shown that they might have a substantial impact on their invertebrate prey (Daborn et al., 1993; Masero et al., 1999; Dierschke et al., 1999a, b; Zharikov and Skilleter, 2003), or even that their intertidal habitat might not provide enough resources to sustain their populations (Smart and Gill, 2003). On BM, shorebirds have been observed to ingest smaller and smaller annelids as they depleted the stock of bigger ones (Boileau and Corre, 2003). However, it has conversely been argued that the shorebird populations might not systematically control benthic prey populations (Wilson and Parker, 1996).

Contrary to shorebirds, juvenile fish ate more during summer than during winter in relation to their respective life cycle. The total fraction of macrofauna biomass preyed upon by juvenile fish reached 3.3\% and 1.1\% during summer and winter in AC and 89\% and 28\% during summer and winter respectively in BM, which lead to an annual consumption of $16 \%$ and $137 \%$ of macrofauna biomass in AC and BM respectively. These values seem very high, and would necessitate a high secondary production to be sustained. Both AC and BM are known as nurseries (Le Pape et al., 2003b; Guérault et al., 1996) and so might well be exploited by this compartment at an important rate also. The role of mudflats for juvenile soles has been emphasized in the Bay of Biscay, but above all for their habitat characteristics and importance for sole recruitment (Le Pape et al., 2003a, b). Besides, juvenile fish might prey also on meiofauna (Castel and Lasserre, 1982; Marinelli and Coull, 1987; Amara and Bodin, 1995), and hence have a wider range of feeding opportunities all year round. As the model showed no predation of juvenile fish on meiofauna, one can suppose that there is still a food reservoir, but with the restriction that they might enter into competition with other predators of meiofauna.

Hence, the conclusion is that the impact of shorebirds and juvenile fish is lower in AC than in BM, and that further studies on macrofauna production would be useful.

\subsection{Comparison of seasonal coupling in the two systems}

The contrast between the two seasons in BM, which could not previously be observed with the year-round average modelling (Leguerrier et al., 2003, 2004), emphasized the usefulness of dividing the year into two complementary periods. Indeed, BM presented two much contrasted seasons, whereas AC seemed to be functioning more homogeneously throughout the year.

The warm season appeared as the main producing season. Variation in living biomass was positive for the two systems during summer, with a decrease only in the gastropod population in AC, and in the nematode, annelid and arthropod populations in BM. It is interesting to note that annelids and nematodes were amongst the most impacted compartments according to the sensitivity analyses carried out on BM, as were gastropods for AC. A decrease is also observed in the amount of pelagic detritus in winter and of benthic detritus in summer on $\mathrm{BM}$, whereas the summer is a season of (pelagic and benthic) detritus accumulation in AC. This is linked to the inputs which were more important during summer than during winter for AC and greater in winter than in summer in BM.

The two systems are very similar in term of surface, sediment type or current speed, and differ a few on mudflat morphology (ridges and runnels on the BM mudflat and gentler bottom slope than on the AC mudflat). But those little differences in mudflat morphology had no 
significative consequence on the benthic activities of microphytobenthos, nematodes, foraminifera or macrofauna. The major difference between the two systems is the amount of shellfish culture. The importance of oysterculture on BM induces trivially a greater activity of cultivated bivalves, but also a greater benthic detritus accumulation on BM than on AC. However the activity of mullets seamed greater on AC than on BM, even if this result came only from model calculation and should be verified in field.

The food-web organisation also changed between summer and winter. Indeed, the nematode populations are more numerous in winter than in summer (Rzeznik-Orignac et al., 2003), contrary to what is supposed for macrofauna. The nematode dynamics have been studied in BM (Rzeznik-Orignac et al., 2003), but not in AC, and the sensitivity analyses showed that grazing rate by nematodes had a significant impact on the results: the question is wether, with more information on this compartment, different patterns would be observed in AC. It had already been demonstrated that nematodes are an important compartment for benthic communities (Gerlach, 1971), at the detrital level (Escaravage et al., 1989), in the transfer of material towards higher trophic levels (Coull, 1990). It is emphasized here that they may also play a structural role by forcing the trophic organization of the ecosystem. Schmid-Araya et al. (2002) suggested that meiofauna play a key role as intermediate between trophic levels and that adding this compartment in a conceptual model highly increases its complexity. Hence, in the choice of aggregation level in the conceptual model, meiofauna should not be omitted. These observations on meiofauna, macrofauna and predators underline the necessity of coupling two seasons in the modelling of a food web, provided that enough information is available to characterize the seasonal patterns of the populations.

\subsection{Global functioning}

The overall activity (sum of all the fluxes) in BM was 1.5 times higher than in AC, because of the greater benthic activity in BM than in AC (Table 6). However the two mudflats presented similar global functioning, with a net organic-carbon import from the ocean, net export of primary production, a predominance of benthic primary production over pelagic primary production due to their high turbidities (Blanchard and Cariou Le Gall, 1994) and dominating consumption on detritus. Like the benthic system in the Bay of Saint-Brieuc (Chardy et al., 1993), but with a much higher benthic primary production, they both imported material from the water column. The bentho-pelagic ecosystem annually used $28 \%$ of the imported pelagic material in AC, $7 \%$ in BM, and 54\% in the Bay of Saint Brieuc benthic ecosystem.

However, these imports and exports were different in terms of proportions of phytoplankton, zooplankton and detritus. In both systems and for both seasons, the imports presented a higher percentage of non-living material than the exports. Comparison with other results from the literature showed that this is not always the case in estuaries. Indeed several estuaries present net quality importations (e.g. Kromme Estuary in Baird et al., 1991, Swartkops and Ythan Estuaries in Baird and Ulanowicz, 1993, or Seine Estuary in Rybarczyk and Elkaïm, 2003). The ratio of detritivory over herbivory shows that detritivory is high in the two systems (Table 6), and especially in BM. The BM values (6 during summer and 7.5 during winter) are close to what had been estimated for the Chesapeake Bay (6.90 in Monaco and Ulanowicz, 1997). In comparison, lower values had been observed in the Seine Estuary (2.52 in Rybarczyk and Elkaïm, 2003) or Delaware Bay (3.4 in Baird and Ulanowicz, 1993), but higher values had been calculated for Narragansett Bay (8.10), Swartkops Estuary (10.2) Ythan Estuary (13.26), Kromme Estuary (22.5) (in Baird and Ulanowicz, 1993).

This description of the functioning of these two close estuarine systems underlines the central role of detritus imports and microphytobenthic primary production. These two elements 
are closely related to the geography of the two sites. The river inputs are the main entry of nonliving organic carbon. The surface of the mudflat determines the quantity of primary producing diatom biofilm. These two elements are essential for the functioning comparison between ecosystems. The river inputs play directly on the available detritus, shown to be essential organic carbon elements in the functioning of estuarine systems (Mc Lusky, 1989). Recent food web models also show that detritus consumption flows play a major role in increasing the ecosystem stability and persistence (Moore et al., 2004). The other main source of organic carbon is the primary production by the microphytobenthos. The surface of intertidal mudflat is a key factor in controlling this production at the ecosystem scale. This is why the observation of the decrease of this producing area could be of great consequence on the ecological functioning of the ecosystem (Dauvin and Desroy, 2005). The interaction with areas, either connected to the intertidal ecosystem by physical exchanges (mainly an enrichment of microphytobenthos), or by biotic vectors (fishes and birds), could also lead to a larger extent of this consequence.

\section{Conclusion}

Two ecosystems, known to different extents, were modelled and compared. The differences and similarities agree with the current knowledge about the 2 sites and raise new questions that will be addressed in further field experiments. For example, the differences in the level of knowledge suggested new investigations on the mullet compartment.

From the points of similarity observed at the two sites, an overall description of the two systems can be sketched: 1) they were sensitive to inputs from both rivers and ocean. The "tidal pump" (so called after Odum, 1980) is illustrated by material supplying, mixing and water column renewing. 2) The exchanges with the "outside" show, at an annual scale, net imports of detritus and net exports of phytoplankton, micro- and mesozooplankton. This corresponds to a net export of quality during each season. 3) During both seasons, detritivory was the most important diet in both systems which also showed a high diversity of resource utilization.

\section{Acknowledgement}

This work was supported by grants from ONCFS on shorebirds and benthos interactions (D. Degré PhD grant), from IFREMER on fisheries and bivalve culture interactions (D. Leguerrier PhD and N. Niquil Program grant), from the French Ministry of Research (ACI-ECCO) and of Agriculture - ENGREF (D. Leguerrier PhD grant). We thank T. Pineau (mussel farmer in AC) for the sampling on board of the KTEMA, and M. Breret, F. Mornet and P. Pineau (CREMA technicians) for their help to D. Degré in sampling and analysing cores in AC. We also thank Ian Jenkinson for correction of the English, and Pierre-Yves Pascal for useful discussions about the manuscript. 


\section{References}

Almeida, P.R., 2003. Feeding ecology of Liza ramada (Risso, 1810) (Pisces, Mugilidae) in a south-western estuary of Portugal. Estuarine, Coastal and Shelf Science 57, 313-323.

Altenbach, A.V., 1992. Short term processes and patterns in the foraminiferal response to organic flux rate. Marine Micropaleontology 19, 119-129.

Amara, R., Bodin, P., 1995. L'environnement trophique méiobenthique en dehors des nourriceries côtières est-il favorable à l'installation de jeunes soles? Oceanologica Acta 18, 583-590.

Armynot du Chatelet, E., Debenay, J.-P., Degré, D., Sauriau, P.-G., 2005. Utilisation des foraminifères benthiques comme indicateurs de paléo-niveaux marins ? Etude du cas de l'anse de l'Aiguillon. Comptes Rendus Palevol. 4, 209-223.

Bachelet, G., 1982. Quelques problèmes liés à l'estimation de la production secondaire. Cas des bivalves Macoma balthica et Scrobicularia plana. Oceanologica Acta 5, 421-431.

Baird, D., Ulanowicz, R.E., 1989. The seasonal dynamics of the Chesapeake Bay ecosystem. Ecological Monographs 59, 329-364.

Baird, D., Ulanowicz, R.E., 1993. Comparative study on the trophic structure, cycling and ecosystem properties of four tidal estuaries. Marine Ecology Progress Series 99, 221237.

Baird, D., McGlade, J.M., Ulanowicz, R.E., 1991. The comparative ecology of six marine ecosystems. Philosophical Transactions of the Royal Society of London. Series B. Biological Sciences 333, 15-29.

Bassoullet, P., Le Hir, P., Gouleau, D., Robert, S., 2000. Sediment transport over an intertidal mudflat: field investigations and estimation of fluxes within the "Baie de MarennesOléron" (France). Continental Shelf Research 20, 1635-1653.

Blanchard, G.F., Cariou-Le Gall, V., 1994. Photosynthetic characteristics of microphytobethos in Marennes-Oléron Bay, France: preliminary results. Journal of Experimental Marine Biology and Ecology 182, 1-14.

Blanchard, G.F., Simon-Bouhet, B., Guarini, J.-M., 2002. Properties of the dynamics of intertidal microphytobenthic biomass. Journal of the Marine Biological Association of the United Kingdom 82, 1-2.

Blanchard, G.F., Guarini, J.-M., Richard, P., Gros, P., 1997. Seasonal effect of the relationship between the photosynthetic capacity of intertidal microphytobenthos and temperature. Journal of Phycology 33, 723-728.

Blanchard, G.F., Guarini, J.-M., Bacher, C., Huet, V., 1998. Contrôle de la dynamique à court terme du microphytobenthos intertidal par le cycle exondation-submersion. Compte Rendu de l' Académie des Sciences de Paris, Sciences de la vie / Life Sciences 321, 501508.

Blanchard, G.F., Guarini, J.-M., Orvain, F., Sauriau, P.-G., 2001. Dynamic behaviour of benthic microalgal biomass in intertidal mudflats. Journal of Experimental Marine Biology and Ecology 264, 85-100. 
Boileau, N., Corre, F., 2003. Densité hivernale et régime alimentaire du pluvier argenté Pluvialis squatarola dans le Centre-Ouest de la France. Alauda 71, 3601.

Bruslé, J., 1981. Food and feeding in grey mullets. In: Oren, O.H. (Ed.), Aquaculture of grey mullets. Cambridge University Press, Cambridge, pp. 185-217.

Burger, J., Niles, L., Clark, K.E., 1996. Importance of beach, mudflat and marsh habitats to migrant shorebirds on Delaware Bay. Biological Conservation 79, 283-292.

Cariou-Le Gall, V., Blanchard, G.F., 1995. Monthly HPLC measurements of pigment concentration from an intertidal muddy sediment of Marennes-Oléron Bay, France. Marine Ecology Progress Series 121, 171-179.

Castel, J., Lasserre, P., 1982. Régulation biologique du méiobenthos d'un écosystème lagunaire par un allevinage expérimental en soles (Solea vulgaris). Oceanologica Acta $n^{\circ}$ sp, 243251.

Chardy, P., Dauvin, J.-C., 1992. Carbon flows in a subtidal fine sand community from the western English Channel: a simulation ANALYSIS. Marine Ecology Progress Series 81, 147-161.

Chardy, P., Gros, P., Mercier, H., Monbet, Y., 1993. Benthic carbon budget for the Bay of Saint Brieuc (Western Channel). Application of inverse method. Oceanologica Acta 16, 687694.

Coull, B.C., 1990. Are members of the meiofauna food for higher trophic levels? Transactions of the American Microscopical Society 109, 233-246.

Daborn, G.R., Amos, C.R., Brylinski, M., Christian, H., Drapeau, G., Faas, R.W., Grant, J., Long, B., Paterson, D.M., Perillo, G.M.E., Piccolo, M.C., 1993. An ecological cascade effect: migratory birds affect stability of intertidal sediments. Limnology and Oceanography 38, 225-231.

Dauvin, J.-C., Desroy, N., 2005. The food web in the lower part of the Seine estuary: A synthesis of existing knowledge. Hydrobiologia, 540, 13-27.

Degré, D., Sauriau, P.-G., Haubois, A.-G., 2003. Variabilité temporelle des peuplements de bivalves et de la structure de population de Scrobicularia plana sur la vasière de Montportail-Brouage (S-O, France). Journal de Recherche Océanographique 1-2, 28-33.

Dierschke, V., Kube, J., Rippe, H., 1999b. Feeding ecology of dunlins Calidris alpina staging in the southern Balric Sea, 2. Spatial and temporal variations in the harvestable fraction of their favourite prey Hediste diversicolor. Journal of Sea Research 42, 65-82.

Dierschke, V., Kube, J., Probst, S., Brenning, U., 1999a. Feeding ecology of dunlins Calidris alpina staging in the southern Baltic Sea, 1. Habitat use and food selection. Journal of Sea Research 42, 49-64.

Donali, E., Olli, K., Heiskanen, A.-S., Andersen, T., 1999. Carbon flow patterns in the planktonic food web of the Gulf of Riga, the Baltic Sea: a reconstruction by the inverse method. Journal of Marine Systems 23, 251-268.

Escaravage, V., Garcia, M.E., Castel, J., 1989. The distribution of meiofauna and its contribution to detritic pathways in tidal flats (Arcachon Bay, France). Topics in marine biology. Ros J.D. (ed) 53, 551-559.

Essink, K., Beukema, J.J., Coosen, J., Craeymeersch, J.A., Ducrotoy, J.-P., Michaelis, H., Robineau, B., 1991. Population dynamics of the bivalve mollusc Scrobicularia plana da Costa: comparisons in time and space. In: Elliott, M., Ducrotoy, J.-P. (Eds.), Estuaries and Coasts: spatial and temporal intercomparisons. ECSA 19 Symposium. Olsen \&Olsen, pp. 167-172.

Gailhard, I., Gros, P., Durbec, J.P., Beliaeff, B., Belin, C., Nézan, E., Lassus, P., 2002. Variability patterns of microphytoplankton communities along the French coasts. Marine Ecology Progress Series 242, 39-50. 
Gerlach, S.A., 1971. On the importance of meiofauna for benthos communities. Oecologia 6, 176-190.

Gouleau, D., Jouanneau, J.M., Weber, O., Sauriau, P.G., 2000. Short- and long-term sedimentation on Montportail-Brouage intertidal mudflat, Marennes-Oléron Bay, France. Continental Shelf Research 20, 1513-1530.

Goulletquer, P., Héral, M., 1997. Marine molluscan production trends in France: from fisheries to aquaculture. In: MacKensie, C.L., Bunell, V.G., Rosenfield, A. (Eds.), The history, present condition, and future of the Molluscan fishereis of North America and Europe. NOAA Technical Report NMFS 129, Department of Commerce, Seattle, Washington, pp. 137-164.

Goulletquer, P., Le Moine, O., 2002. Shellfish farming and Coastal Zone Management (CZM) development in Marennes-Oléron Bay and Charentais Sounds (Charente-Maritime, France): A review of recent developments. Aquaculture International 10, 507-525.

Guarini, J.M., Blanchard, G.F., Gros, P., 2000. Quantification of the microphytobenthic primary production in European intertidal mudflats - a modelling approach. Continental Shelf Research 20, 1771-1788.

Guarini, J.M., Blanchard, G.F., Bacher, C., Gros, P., Riera, P., Gouleau, D., Galois, R., Prou, J., Sauriau, P.G., 1998. Dynamics of spatial patterns of microphytobenthic biomass: inferences from a geostatistical analysis of two comprehensive surveys in MarennesOléron Bay (France). Marine Ecology Progress Series 166, 131-141.

Guarini, J.-M., Gros, P., Blanchard, G., Richard, P., Fillon, A., 2004. Benthic contribution to pelagic microalgal communities in two semi-enclosed, European-type littoral ecosystems (Marennes-Oléron Bay and Aiguillon Bay, France). Journal of Sea Research 52, 241-258.

Guérault, D., Dorel, D., Désaunay, Y., 1996. Cartographie des nourriceries littorales de poissons du Golfe de Gascogne. IFREMER/MAPA/DPMCM, Nantes.

Haubois, A.-G., Guarini, J.-M., Richard, P., Blanchard, G.F., Sauriau, P.-G., 2002. Spatiotemporal differentiation in the population structure of Hydrobia ulvae on an intertidal mudflat. Journal of the Marine Biological Association of the United Kingdom 82, 605614.

Haubois, A.-G., Guarini, J.-M., Richard, P., Hemon, A., Arotcharen, E., Blanchard, G.F., 2004. Differences in spatial structures between juveniles and adults of the gastropod Hydrobia ulvae on an intertidal mudflat (Marennes-Oléron Bay, France) potentially affect estimates of local demographic processes. Journal of Sea Research 51, 63-68.

Haubois, A.-G., Guarini, J.-M., Richard, P., Fichet, D., Radenac, G., Blanchard, G.F., 2005. Ingestion rate of the deposit-feeder Hydrobia ulvae (Gastropoda) on epipelic diatoms: effect of cell size and angal biomass. Journal of Experimental Marine Biology and Ecology 317, 1-12.

Jackson, G.A., Eldridge, P.M., 1992. Food web analysis of a planktonic system off southern California. Progress in Oceanography 30, 223-252.

Jørgensen, S.E., Müller, F., 2000. Towards a unifying theory. In: Jørgensen, S.E., Müller, F. (Eds.), Handbook of ecosystem theories and management. Lewis Publisher, CRC Press LLC, pp. 465-471.

Joyeux, E., 2001. Les prés salés de la baie de l'Aiguillon. Intérêt et enjeux. In: Drévès, L., Chaussepied, M. (Eds.), Restauration des écosystèmes côtiers. Ifremer, Brest, pp. 143152.

Laffaille, P., Feunteun, E., Lefebvre, C., Radureau, A., Sagan, G., Lefeuvre, J.-C., 2002. Can thin-lipped mullet direcly exploit the primary and detritic production of European macrotidal salt marshes? Estuarine, Coastal and Shelf Science 54, 729-736. 
Lagardère, J.P., 1987. Feeding ecology and daily food consumption of common sole, Solea vulgaris, Quensel, juveniles on the French Atlantic Coast. Journal of Fish Biology 30, 91-104.

Le Hir, P., Roberts, W., Cazaillet, O., Christie, M., Bassoulet, P., Bacher, C., 2000. Characterization of intertidal flat hydrodynamics. Continental Shelf Research 20, 14331459.

Le Pape, O., Holley, J., Guérault, D., Désaunay, Y., 2003a. Quality of coastal and estuarine essential fish habitats: estimations based on the size of juvenile common sole (Solea solea L.). Estuarine, Coastal and Shelf Science 58, 793-803.

Le Pape, O., Chauvet, F., Mahévas, S., Lazure, P., Guérault, D., Désaunay, Y., $2003 b$. Quantitative description of habitat suitability for the juvenile common sole (Solea solea L.) in the Bay of Biscay (France) and the contribution of different habitats to the adult population. Journal of Sea Research 50, 139-149.

Leguerrier, D., Niquil, N., Petiau, A., Bodoy, A., 2004. Modeling the impact of oyster culture on a mudflat food web in Marennes-Oléron Bay (France). Marine Ecology Progress Series 273, 147-162.

Leguerrier, D., Niquil, N., Boileau, N., Rzeznik, J., Sauriau, P.-G., Le Moine, O., Bacher, C., 2003. Numerical analysis of the food web of an intertidal mudflat ecosystem on the Atlantic coast of France. Marine Ecology Progress Series 246, 17-37.

Marinelli, R.L., Coull, B.C., 1987. Structural complexity and juvenile fish predation on meiobenthos: an experimental approach. Journal of Experimental Marine Biology and Ecology 108:67-81.

Masero, J.A., Pérez-Gonzalez, M., Basadre, M., Otero-Saavedra, M., 1999. Food supply for waders (Aves: Charadrii) in an estuarine area in the Bay of Cadiz (SW Iberian Peninsula). Acta Oecologica 20, 429-434.

Mc Lusky, D.S., 1989. The estuarine ecosystem. Blackie and Son Ltd, Glasgow, 215 pp.

Meire, P.M., Schekkerman, H., Meininger, P.L., 1994. Consumption of benthic invertebrates by waterbirds in the Oosterschelde estuary, SW Netherlands. Hydrobiologia 282/283, 525546.

Menesguen, A., Hoch, T., 1997. Modelling the biogeochemical cycles of elements limiting primary production in the English Channel. I. role of thermohaline stratification. Marine Ecology Progress Series 146, 173-188.

Monaco, M.E., Ulanowicz, R.E., 1997. Comparative ecosystem trophic structure of three US mid-Atlantic estuaries. Marine Ecology Progress Series 161, 239-254.

Montaudouin (de), X., Sauriau, P.-G., 2000. Contribution to a synopsis of marine species richness in the Pertuis Charentais Sea with new insights in soft-bottom macrofauna of the Marennes-Oléron Bay. Cahiers de Biologie Marine 41, 181-222.

Moore, J.C., Berlow, E.L., Coleman, D.C., De Suiter, P.C., Dong, Q., Hastings, A., Johnson, N.C., McCann, K.S., Melville, K., Morin, P.J., Nadelhoffer, K., Rosemond, A.D., Post, D.M., Sabo, J.L., Scow, K.M., Vanni, M.J., Wall, D.H., 2005. Correspondence address Detritus, trophic dynamics and biodiversity. Ecology letters 7, 584-600.

Morrison, M.A., Francis, M.P., Hartill, B.W., Parkinson, D.M., 2002. Diurnal and Tidal Variation in the Abundance of the Fish Fauna of a Temperate Tidal Mudflat. Estuarine, Coastal and Shelf Science 54, 793-807.

Niquil, N., Jackson, G.A., Legendre, L., Delesalle, B., 1998. Inverse model analysis of the planktonic food web of Takapoto Atoll (French Polynesia). Marine Ecology Progress Series 165, 17-29. 
Odum, E.P., 1980. The status of three ecosystem-level hypotheses regarding salt marsh estuaries: tidal subsidy, outwelling, and detritus-based food chains. In: Kennedy, V.A. (Ed.), Estuarine perspectives. Academic Press, London, pp. 485-495.

Orvain, F., 2005. A model of sediment transport under the influence of surface bioturbation: generalisation to the facultative suspension-feeder Scrobicularia plana. Marine Ecology Progress Series 286, 43-56.

Orvain, F., Le Hir, P., Sauriau, P.G., 2003. A model for fluff layer erosion and subsequent bed erosion in the presence of the bioturbator Hydrobia ulvae. Journal of Marine Research 61, 823-851.

Orvain, F., Sauriau, P.G., Sygut, A., Joassard, L., Le Hir, P., 2004. Interacting effects of Hydrobia ulvae bioturbation and microphytobenthic on the erodability of mudflat sediments. Marine Ecology Progress Series 278, 205-223.

Parker, R.L., 1994. Geophysical inverse theory. Princeton University Press, Princeton, New Jersey, $400 \mathrm{pp}$.

Roberts, W., Le Hir, P., Whitehouse, R.J.S., 2000. Investigation using simple mathematical models of the e!ect of tidal currents and waves on the profile shape of intertidal mudflats. Continental Shelf Research 20 (10/11), 1079-1097.

Rybarczyk, H., Ellkaïm, B., 2003. An analysis of the trophic network of a macrotidal estuary: the Seine Estuary (Eastern Channel, Normandy, France). Estuarine, Coastal and Shelf Science 58, 775-791.

Rzeznik-Orignac, J., Fichet, D., Boucher, G., 2003. Spatio-temporal structure of the nematode assemblages of the Brouage mudflat (Marennes-Oléron Bay, France). Estuarine, Coastal and Shelf Science 58, 77-88.

Saltelli, A., Chan, K., Scott, E.M., 2000. Sensitivity Analysis. John Wiley \& Sons, New York, $504 \mathrm{pp}$.

Sauriau, P.G., Mouret, V., Rincé, J.-P., 1989. Organisation trophique de la malacofaune benthique non cultivée du bassin ostréicole de Marennes-Oléron. Oceanologica Acta 12, 193-204.

Sautour, B., Castel, J., 1993. Distribution of zooplankton populations in Marennes-Oléron Bay (France), structure and grazing impact of copepod communities. Oceanologica Acta 16, 279-290.

Schmid-Araya, J.M., Hildrew, A.G., Robertson, A., Schmid, P.E., Winterbottom, J., 2002. The importance of meiofauna in food webs: evidence from an acid stream. Ecology 83, 1271-1285.

SHOM, 2001. Courants de marée de la côte ouest de France de Saint-Nazaire à Royan. Servie Hydrographique et Océanographique de la Marine (Ed.), Brest, 72 pp.

Smart, J., Gill, J.A., 2003. Non-intertidal habitat use by shorebirds: a reflection of inadequate intertidal resources? Biological Conservation 111, 359-369.

Soletchnik, P., Faury, N., Razet, D., Goulletquer, P., 1998. Hydrobiology of the MarennesOléron Bay. Seasonal indices and analysis of trends from 1978 to 1995 . Hydrobiologia 386, 131-146.

Solidoro, C., Crise, A., Crispi, G., Pastres, R., 2003. An a priori approach to assimilation of ecological data in marine ecosystem models. Journal of Marine Systems 40-41.

Struski, C., Bacher, C., in press. Preliminary estimate of primary production by phytoplankton in Marennes-Oléron Bay, France. Estuarine Coastal and Shelf Science.

Triplet, P., Le Dréan-Quénec'hdu, S., Mahéo, R., 2001. Incidence des infrastructures portuaires et des activités humaines sur l'abondance et la répartition des limicoles sur le littoral français. In: Drévès, L., Chaussepied, M. (Eds.), Restauration des écosystèmes côtiers. Ifremer, Brest, pp. 243-255. 
Ulanowicz, R.E., 1986. Growth and development: ecosystem phenomenology. Springer-Verlag, New York, 203 pp.

Verger, F., 1968. Marais et wadden du littoral français. Biscaye frères, Bordeaux, 541 pp.

Vézina, A.F., 1989. Construction of flow networks using inverse methods. In: Wulff, F., Field, J.G., Mann, K.H. (Eds.), Network analysis in marine ecology. Methods and applications. Springer-Verlag, Berlin.

Vézina, A.F., Platt, T., 1988. Food web dynamics in the ocean. I. Best estimates using inverse methods. Marine Ecology Progress Series 42, 269-287.

Vézina, A.F., Savenkoff, C., 1999. Inverse modelling of carbon and nitrogen flows in the pelagic food web of the north-east subarctic Pacific. Deep-Sea Research 46, 2909-2939.

Wilson, W.H., Parker, K., 1996. The life history of the amphipod, Corophium volutator: the effects of temperature and shorebird predation. Journal of Experimental Marine Biology and Ecology 196, 239-250.

Winemiller, K.O., Polis, G.A., 1996. Food webs: what do they tell us about the world? In: Polis, G.A., Winemiller, K.O. (Eds.), Food webs. Integration of patterns and dynamics. Chapman \& Hall, New York, pp. 1-22.

Wolff, W.J., van Haperen, A.M.M., Sandee, A.J.J., Baptist, H.J.M., Saeijs, H.L.F., 1975. The trophic role of birds in the Grevelingen estuary, The Netherlands, as compared to their role in the saline Lake Grevelingen, 10th European Symposium on Marine Biology, Ostend, Belgium, pp. 673-689.

Yésou, P., 1992. Importance de la baie de l'Aiguillon et de la pointe d'Arçay (Vendée, France) pour les limicoles. L'oiseau et la Revue Française d’Ornithologie 62, 213-233.

Zharikov, Y., Skilleter, G.A., 2003. Depletion of benthic invertebrates by bar-tailed godwits Limosa lapponica in a sub-tropical estuary. Marine Ecology Progress Series 254, 151162. 
Figure 1 :Map of the Charentais Sounds (Pertuis) showing the location of the two study sites the Aiguillon Cove and the Brouage Mudflat.

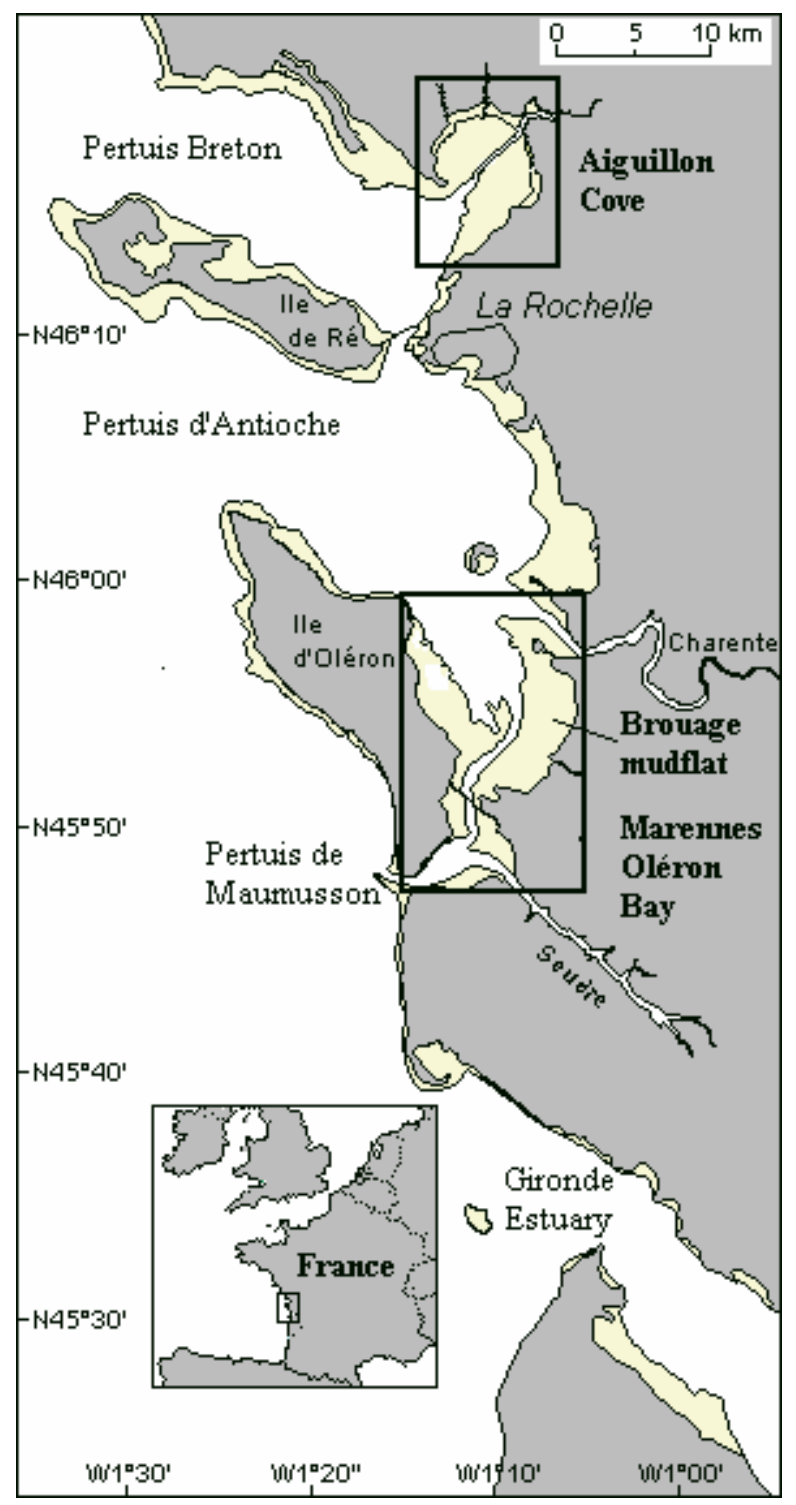


Figure 2: Construction of the matrices $A$ and $G$ and of the vectors $b$ and $h$ for inverse analysis applied on a two-coupled-seasons model. $A_{e}$ is the annual equilibrium equation matrix, $A_{1}$ and $A_{2}$ are the two seasonal equation matrices, $A_{g}$ is the annual equation matrix. $b_{e}$ (null vector), $b_{1}$, $b_{2}$ and $b_{g}$ are the associated right-hand constant vectors. $G_{1}$ and $G_{2}$ are the two seasonal inequality matrices; $G_{g}$ is the annual inequality matrix. $h_{1}, h_{2}, h_{g}$ are the associated solution vectors. $F^{\prime}$ is the transposed vector of $F$, the solution vector, composed of the solution vector $F_{1}$ for season 1 and the solution vector $F_{2}$ for season 2 . These are column vectors and hence appear here in their transposed form: F'.

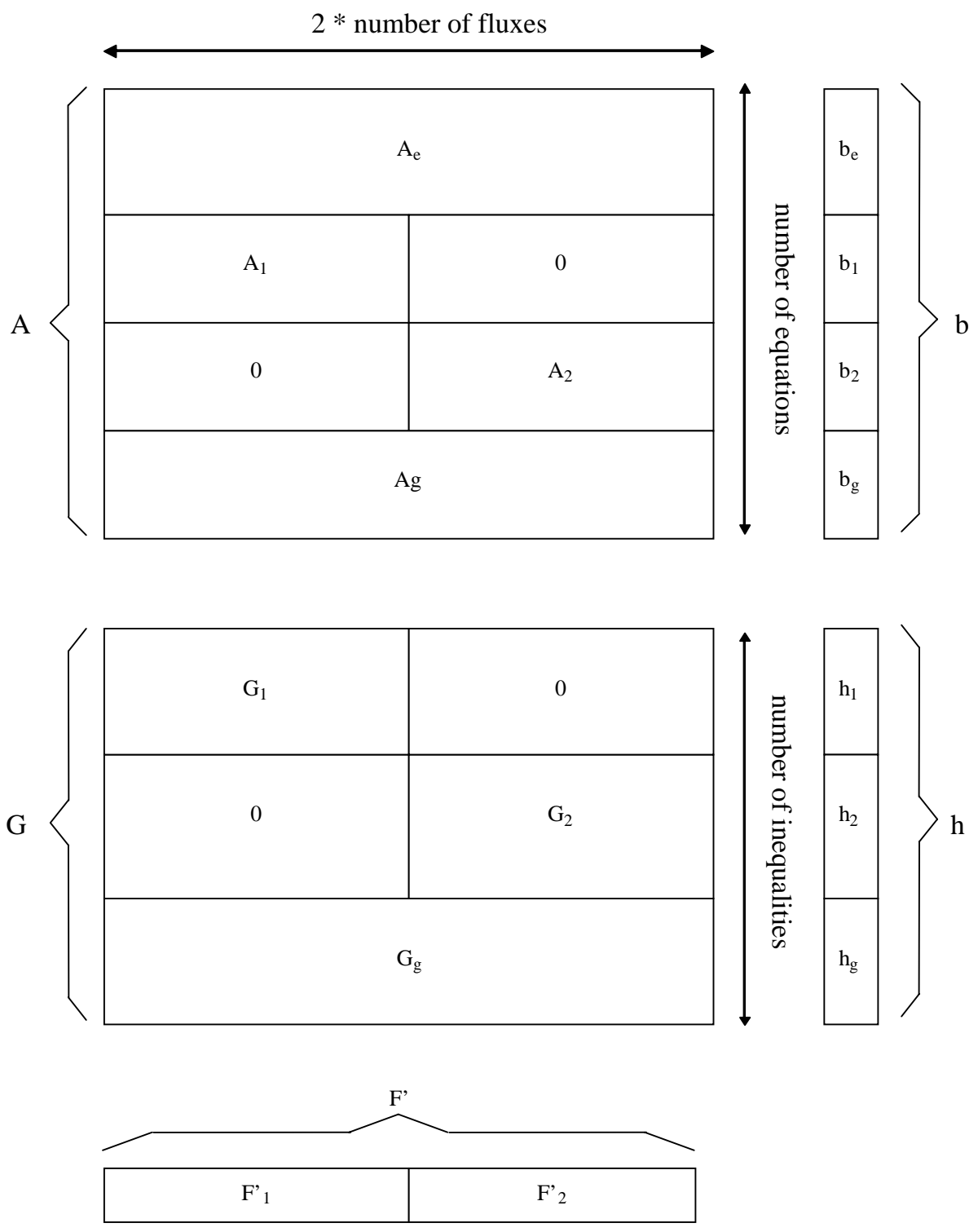


Figure 3: Conceptual model used for the representation of the two food webs. The compartments are those described in Table 1. Arrows represent trophic or physical flows.

"Electric earth" signs represent losses by respiration. Numbers associated with each flux will be the references used in Tables 4 and 5.

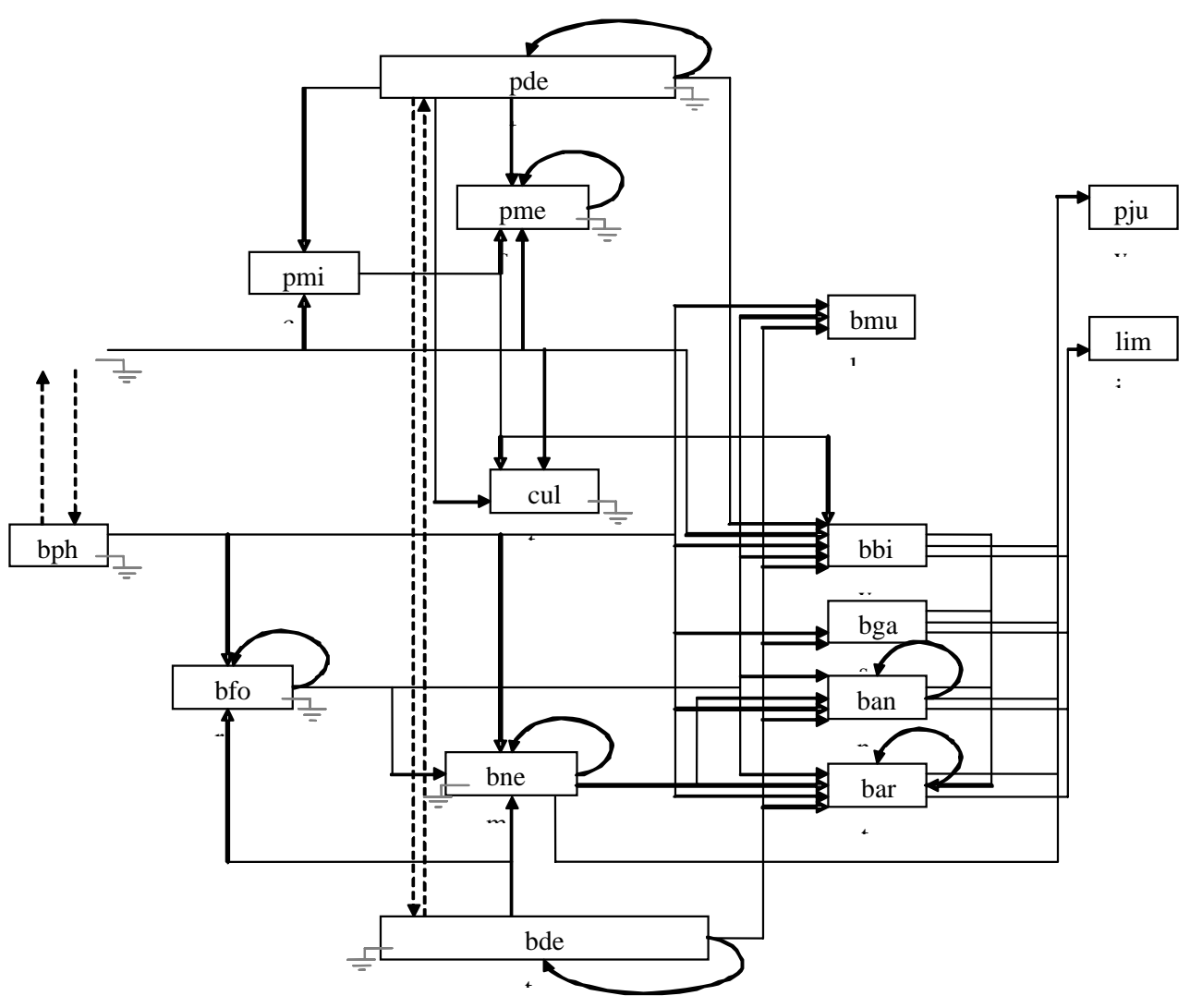


Figure 4: Activities (sum of all inflows) of each compartment for the two seasons (summer and winter) and the two ecosystems . AC summer, AC winter, BM summer and BM winter represent the Aiguillon Cove and Brouage Mudflat ecosystems during summer and winter, respectively. The compartments are referred to by their abbreviations given in Table 1, and are ranked by decreasing order of the sum of the 4 models activities. Values are given in gC.m ${ }^{-}$ ${ }^{2}$. month ${ }^{-1}$.

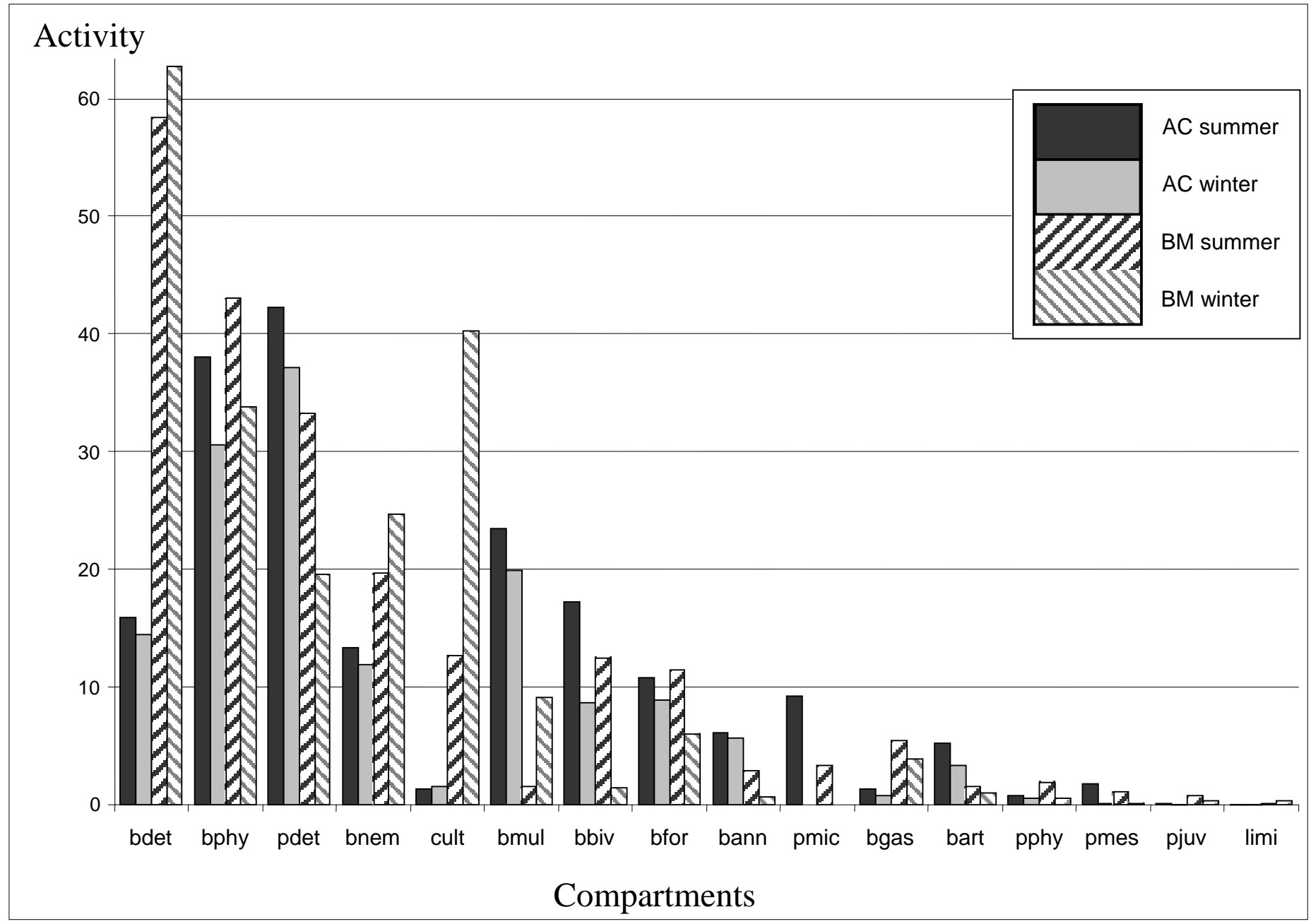


Figure 5: Overall imports and exports of the two systems, with their repartitions between gross primary production and inputs via the water column for the importations ("In"), and respiration, export by shellfish culture and biotic vectors, burial of detritus and outputs via the water column for the exports ("Ex"). Abbreviations AC summer, AC winter, BM summer and BM winter as in Figure 4. The composition of the water column inputs and outputs is given in percentages, 'phy' stands for 'phytoplankton', 'zoo' for 'microzooplankton and mesozooplankton', and 'det' for 'pelagic detritus'. Values are given in gC.m ${ }^{-2}$.month ${ }^{-1}$.

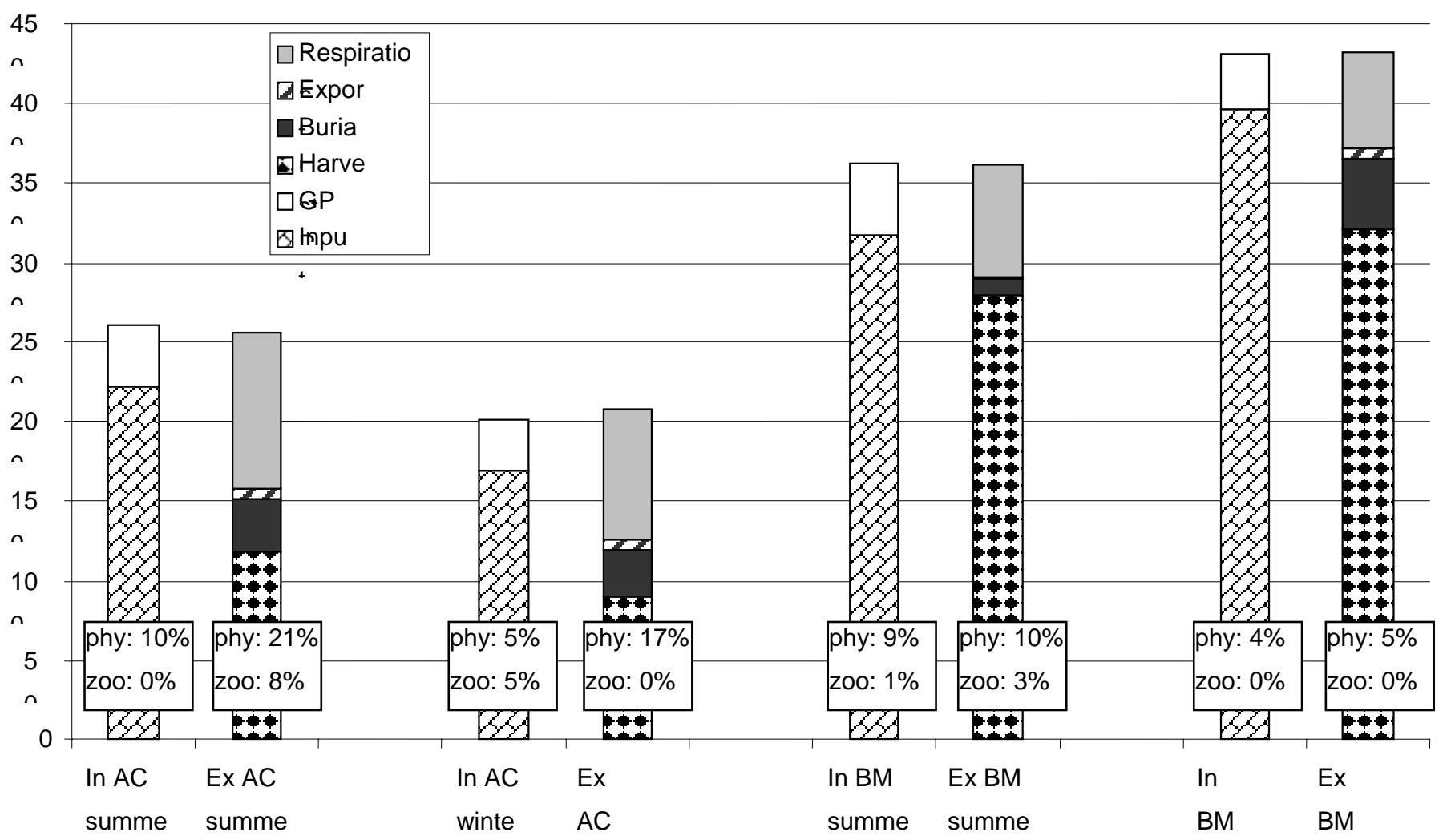


Figure 6: Effect of most influencing parameters on sensitivity analyses in case of Brouage Mudflat (top) and Aiguillon Cove (bottom) models. Parameters are: the total activity of cultured oysters (acty cult), the commercial production of cultured oysters (prod cult), the production of non-cultivated bivalves (prod bbiv), the grazing of nematodes on microphytobenthos (graz bnem), the total inputs from the Marennes-Oléron Bay (inputs) in BM, the resuspension of microphytobenthos (rssp bphy), the microphytobenthos primary production (NPP bphy), the fish grazing on microphytobenthos (graz bmul) and the grazing of gastropods on microphytobenthos (graz bgas), oceanic and river inputs in AC (inputs $\mathrm{O}$ and inputs $\mathrm{R}$ ), the total net primary production (NPP tot) and that of microphytobenthos (NPP bphy). For each model, these parameters are ordered according to the sum of the 4 indices $\mathrm{SI}(\mathrm{P})$, in absolute value. The vertical axis gives the values of the sensitivity analysis index (relative variation of fluxes normalized by the relative variation of parameters, see text for further explanation).

Sensitivity Index

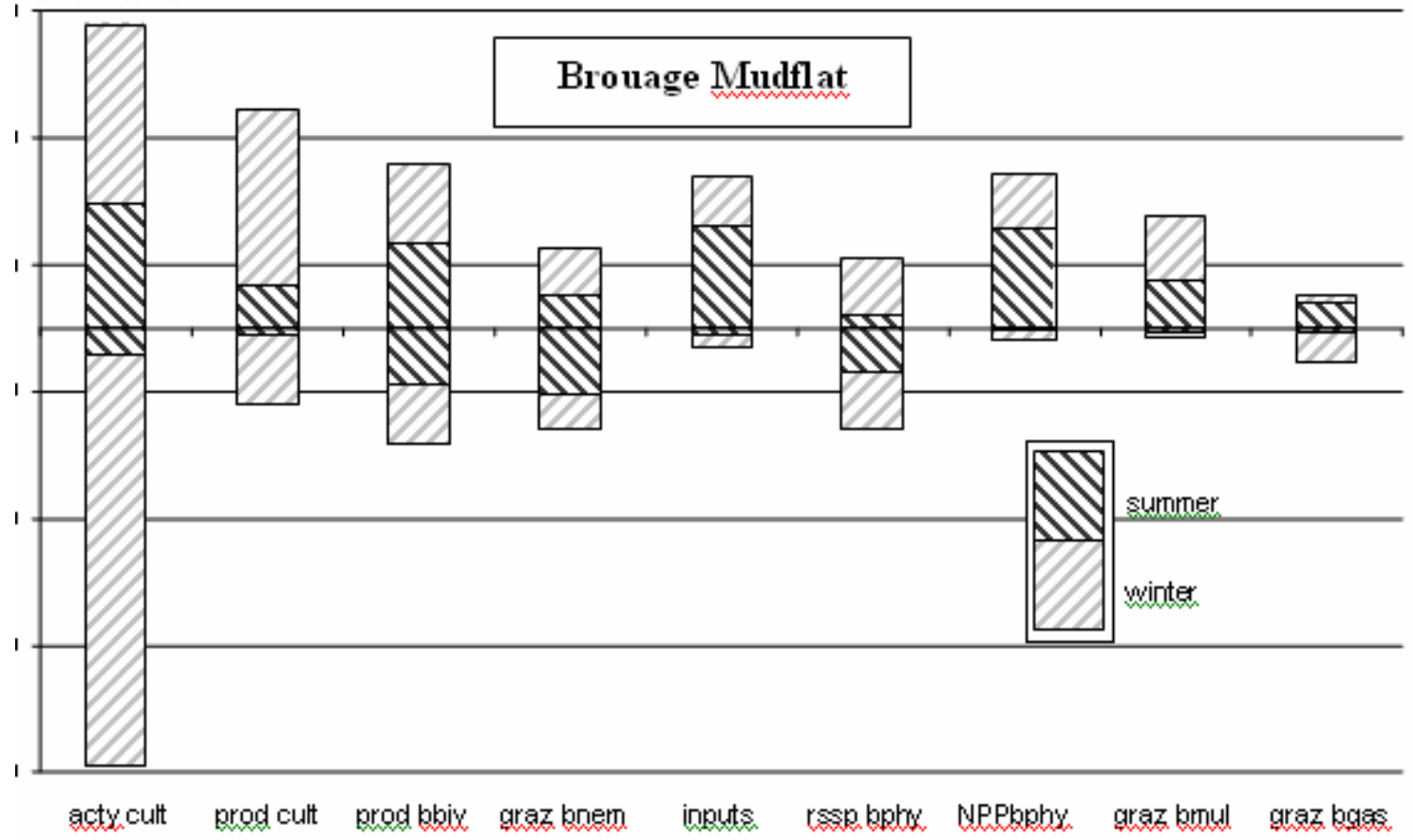




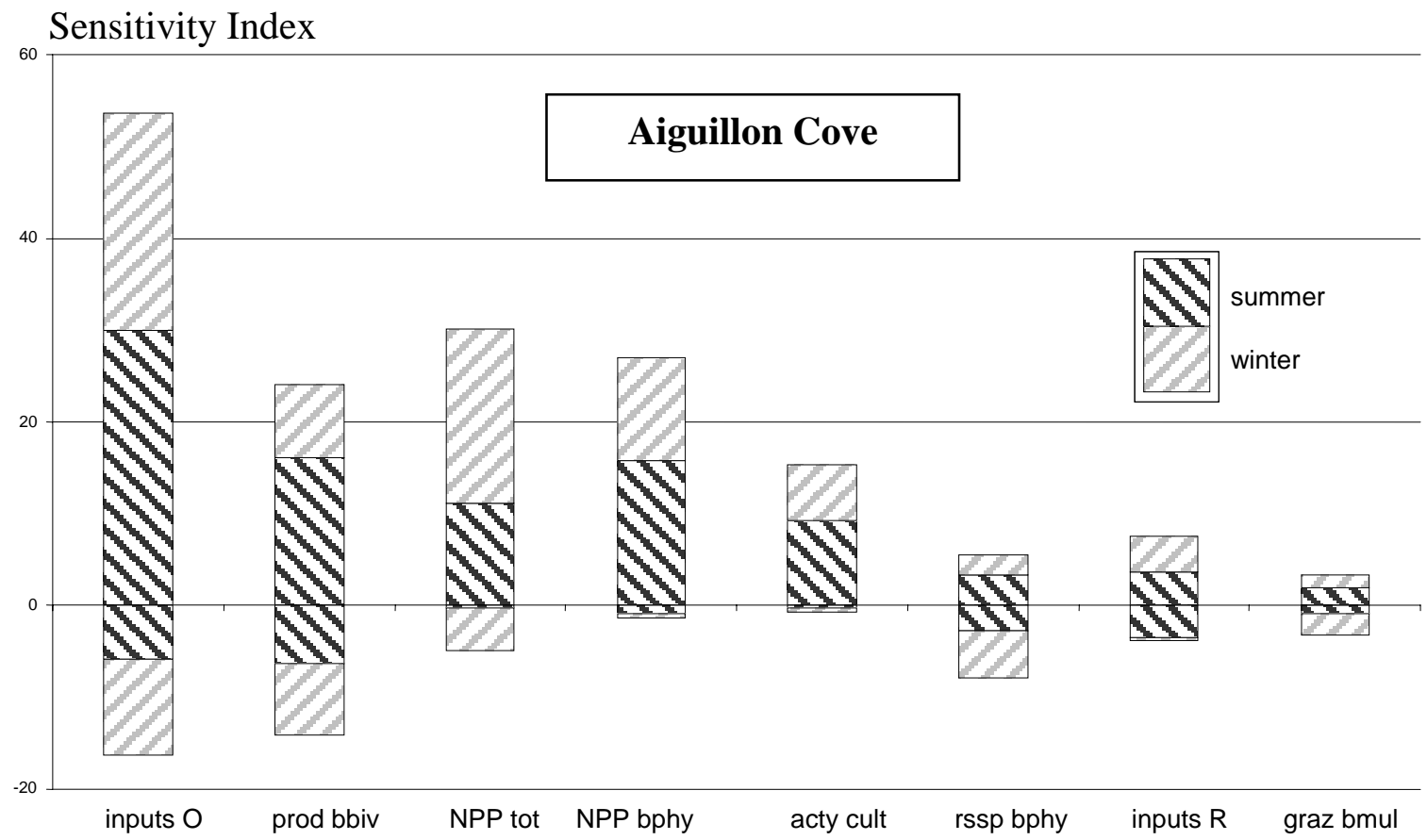


Table 1

Compartments in the Aiguillon Cove (AC) and Brouage Mudflat (BM) food web models. Compartment names are abbreviated (Abb); Biomass values are given when available for March and October, and averaged for the summer and winter periods; Location gives the place where biomasses were measured $(\mathrm{BS}=$ Breton Sound, $\mathrm{BoB}=$ Bay of Biscay and MOB = Marennes-Oléron Bay); pelagic data concentrations in gC. $\mathrm{m}^{-3}$ have been multiplied by the mean water depth above mudflats i.e. $2.5 \mathrm{~m}$ for $\mathrm{BM}$ and $3.3 \mathrm{~m}$ for AC to express all biomasses in gC.m ${ }^{-2}$. The shellfish culture compartment (cult) is composed of Crassostrea gigas in Brouage mudflat and of Crassostrea gigas and Mytilus edulis in Aiguillon cove. Reference: REPHY and RAZLEC refer to IFREMER networks (Gailhard et al., 2002; Soltechnik et al., 1998), (1) Marquis (unpub. data), (2) Armynot du Châtelet et al. (2005), (3) Sautour, 1991 in Sautour and Castel, 1993, (4) Fichet (unpub. data), (5) Degré et al., 2003, (6) Guérault et al., 1996, (7) Joyeux (unpub. data), (8) Guarini et al., 1998, (9) Sautour and Castel, 1993, (10) Rzeznik (unpub. data), (11) Sauriau (unpub. data), (12) Haubois (pers. comm.), (13) Lemoine (pers. comm.), (14) Lagardère, 1987, (15) Guérault et al., 1996, (16) Boileau (pers. comm.), (17) Dupuy (unpub. data), (18) Auguet (unpub. data), (19) Garet, 1996 in Leguerrier et al. 2003.

\begin{tabular}{|c|c|c|c|c|c|c|c|c|c|c|c|c|c|}
\hline \multirow[b]{2}{*}{ Abb } & \multirow{2}{*}{$\frac{\text { Compartment }}{\text { Name }}$} & \multicolumn{6}{|c|}{ Biomass values used in the Aiguillon Cove model } & \multicolumn{6}{|c|}{ Biomass values used for the Brouage Mudflat model } \\
\hline & & March & Summer & October & Winter & Location & Reference & March & Summer & October & Winter & Location & Reference \\
\hline pphy & $\begin{array}{l}\text { phytoplankton \& } \\
\text { resuspended } \\
\text { microphytobenthos }\end{array}$ & 0.466 & 0.709 & 0.438 & 0.222 & BS & REPHY & 0.257 & 0.319 & 0.251 & 0.190 & MOB & RAZLEC \\
\hline bphy & microphytobenthos & 5.600 & & 7.556 & & $\mathrm{AC}$ & (5) & & 3.800 & & 2.450 & $\mathrm{BM}$ & (8) \\
\hline pmic & $\begin{array}{l}\text { pelagic microfauna } \\
\text { (ciliates, flagellates) }\end{array}$ & 0.010 & 0.027 & 0.039 & 0.011 & BoB & (1) & & 0.013 & & 0.013 & $\mathrm{BoB}$ & (1) \\
\hline bfor & benthic foraminifera & & 0.350 & & 0.350 & $\mathrm{AC}$ & $(2)$ & 0.140 & 3.782 & 4.282 & 1.562 & $\mathrm{BM}$ & (2) \\
\hline pmes & $\begin{array}{c}\text { mesozooplancton } \\
\text { (mainly copepods) } \\
\text { meiofauna }\end{array}$ & 0.077 & 0.102 & 0.077 & 0.051 & MOB & (3) & & 0.047 & & 0.038 & MOB & (3), (9) \\
\hline bnem & $\begin{array}{l}\text { (mainly nematods \& a } \\
\text { few copepods) }\end{array}$ & & 0.992 & & 0.992 & $\mathrm{AC}$ & (4) & 0.970 & 0.886 & 0.850 & 1.393 & $\mathrm{BM}$ & (10) \\
\hline bbiv & bivalves & 2.513 & 2.999 & 3.292 & 1.723 & $\mathrm{AC}$ & (5) & 2.502 & & & & $\mathrm{BM}$ & (11) \\
\hline bgas & $\begin{array}{c}\text { gastropods (Hydrobia } \\
\text { ulvae) }\end{array}$ & 0.542 & 1.098 & 1.655 & 1.098 & $\mathrm{AC}$ & (5) & 0.463 & 0.917 & 0.946 & 1.302 & $\mathrm{BM}$ & (12) \\
\hline $\mathrm{nn}$ & annelids \& nemerteans & 1.023 & 0.871 & 0.718 & 0.871 & $\mathrm{AC}$ & (5) & 0.530 & & & & $\mathrm{BM}$ & (11) \\
\hline bart & arthropods & 0.314 & 0.285 & 0.255 & 0.285 & $\mathrm{AC}$ & (5) & 0.384 & & & & $\mathrm{BM}$ & (11) \\
\hline cult & oysters \& mussels & & & & & $\mathrm{AC}$ & (5) & & 6.954 & & & MOB & (13) \\
\hline pjuv & $\begin{array}{l}\text { juvenile fish (mainly } \\
\text { Solea solea) }\end{array}$ & & 0.007 & & 0.007 & BS & (6) & & 0.195 & & 0.195 & MOB & (14), (15) \\
\hline bmul & $\begin{array}{l}\text { grazing fish (mainly } \\
\text { Liza ramada) }\end{array}$ & & & & & & & & & & & $\mathrm{BM}$ & \\
\hline $\operatorname{limi}$ & shorebirds & 0.013 & 0.055 & 0.009 & 0.019 & $\mathrm{AC}$ & (7) & 0.011 & 0.004 & 0.004 & 0.009 & $\mathrm{BM}$ & (16) \\
\hline \multirow{3}{*}{ pdet } & pelagic bacteria (pbac) & & & & & & & 0.064 & 0.194 & 0.241 & 0.130 & $\begin{array}{l}\mathrm{BM}, \\
\mathrm{MOB}\end{array}$ & (17), (18) \\
\hline & $\begin{array}{c}\text { pelagic DOC (pDOC) } \\
\text { (Dissolved Organic } \\
\text { Carbon) } \\
\text { pelagic POC (pPOC) }\end{array}$ & & & & & & & 1.424 & 1.790 & 2.104 & 2.083 & MOB & (18) \\
\hline & $\begin{array}{l}\text { (Particulate Organic } \\
\text { Carbon) }\end{array}$ & & & & & & & 0.099 & 0.623 & 2.408 & 1.047 & MOB & RAZLEC \\
\hline \multirow{3}{*}{ bdet } & benthic bacteria (bbac) & & & & & & & & 0.846 & & 0.846 & $\mathrm{BM}$ & (19) \\
\hline & benthic DOC (bDOC) & & & & & & & & & & & & \\
\hline & benthic POC (bPOC) & & & & & & & & & & & & \\
\hline
\end{tabular}


Table 2

Equations and inequalities used for the computation of inverse analysis on the two sites, concerning seasonal data. Two values (min and max) are given for the inequalities, and one only for the equalities (bold values). All data are given in $\mathrm{gC} \cdot \mathrm{m}^{-2} \cdot \mathrm{month}^{-1}$. All parameters are given, but references are mentioned only if they add to Leguerrier et al. (2003, 2004). (1) with model rate from Barillé et al., 1997, (2) from model calculation (Struski and Bacher, in press).

\begin{tabular}{|c|c|c|c|c|c|c|c|c|c|}
\hline \multirow[b]{3}{*}{ Compartment } & \multirow[b]{3}{*}{ Parameter } & \multicolumn{4}{|c|}{ Aiguillon Cove } & \multicolumn{4}{|c|}{ Brouage Mudflat } \\
\hline & & \multicolumn{2}{|c|}{ Summer } & \multicolumn{2}{|c|}{ Winter } & \multicolumn{2}{|c|}{ Summer } & \multicolumn{2}{|c|}{ Winter } \\
\hline & & $\min$ & $\max$ & $\min$ & $\max$ & $\min$ & $\max$ & $\min$ & $\max$ \\
\hline cult & winter biomass - summer biomass ${ }^{(1)}$ & & & -0.086 & 0.412 & -0.051 & 12.31 & -1.77 & 2.84 \\
\hline bfor & winter biomass - summer biomass & & & -0.14 & 0.14 & \multicolumn{2}{|c|}{0.591} & & \\
\hline bnem & winter biomass - summer biomass & & & -0.28 & 0.28 & \multicolumn{2}{|c|}{-0.094} & & \\
\hline bgas & winter biomass - summer biomass & & & -0.662 & 0.216 & \multicolumn{2}{|c|}{0.061} & & \\
\hline bjuv & winter biomass - summer biomass & & & -0.002 & 0.002 & \multicolumn{2}{|c|}{$\mathbf{0}$} & & \\
\hline bmul & winter biomass - summer biomass & \multicolumn{2}{|c|}{$\mathbf{0}$} & & & \multicolumn{2}{|c|}{$\mathbf{0}$} & & \\
\hline blim & winter biomass - summer biomass & \multicolumn{2}{|c|}{$\mathbf{0}$} & & & \multicolumn{2}{|c|}{$\mathbf{0}$} & \\
\hline pphy & oceanic inputs & \multicolumn{2}{|c|}{20.1} & \multicolumn{2}{|c|}{7.41} & \multicolumn{2}{|c|}{28.68} & \multicolumn{2}{|c|}{15.67} \\
\hline pphy & river inputs & \multicolumn{2}{|c|}{2.85} & \multicolumn{2}{|c|}{1.03} & \multirow{2}{*}{\multicolumn{2}{|c|}{1.21}} & & \\
\hline pmic & oceanic inputs & & & & & & & & \\
\hline pmes & oceanic inputs & & & & & \multicolumn{2}{|c|}{4.52} & & \\
\hline pdet (bacteria) & oceanic inputs & & & & & 17 & & 11 & .43 \\
\hline pdet (non-living) & oceanic inputs & 19 & & 14 & & 10 & & 18 & 7.5 \\
\hline pdet & river inputs & 5. & & 7. & & & & & \\
\hline pdet (dissolved) & oceanic inputs & & & & & 15 & & 18 & 2.2 \\
\hline pdet (bacteria) & export to ocean & & & & & 54 & & & \\
\hline bphy & net primary production & 32 & & 26 & & 32 & & & 67 \\
\hline pphy & net primary production ${ }^{(2)}$ & & & & & 1. & & $\mathbf{0 .}$ & 48 \\
\hline pmes & grazing & 0.5 & & 0. & & 0.8 & & & 174 \\
\hline bnem & grazing & & & & & 13 & & & .53 \\
\hline bbiv & mortality + egestion & 15 & & & & 1. & & 1. & 75 \\
\hline bgas & broutage & 1 & & & & 1. & & & 356 \\
\hline cult & exportation for commercial production & $\mathbf{0 .}$ & & 0. & & 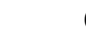 & & 4. & 03 \\
\hline cult & respiration & $\mathbf{0 .}$ & & 0. & & 2 & & & 17 \\
\hline bmul & ingestion & & & & & 1. & & 1. & 58 \\
\hline blim & ingestion & 0.0 & & & & 0. & & $\mathbf{0 . 2}$ & 92 \\
\hline pdet (bacteria) & production & & & & & 2.46 & 3.33 & 0.844 & 1.96 \\
\hline bdet (bacteria) & production & & & & & 30.47 & 51.7 & 17.16 & 29.12 \\
\hline bdet (bacteria) & respiration & & & & & 14.13 & 23.97 & 16.18 & 27.46 \\
\hline pdet & sedimentation by pseudo faeces ${ }^{(1)}$ & & & & & 29 & & 19 & 29 \\
\hline pphy & sedimentation by pseudo faeces ${ }^{(1)}$ & & & & & 2. & & 6. & 08 \\
\hline pdet (bacteria) & sedimentation by pseudo faeces ${ }^{(1)}$ & & & & & 1. & & 3.6 & 86 \\
\hline pphy & respiration (ratio of primary production) & 0.007 & 0.043 & 0.01 & 0.06 & 0.007 & 0.043 & 0.01 & 0.06 \\
\hline pphy & respiration (ratio of primary production) & 0.007 & 0.043 & 0.01 & 0.06 & 0.007 & 0.043 & 0.01 & 0.06 \\
\hline pphy & exudation (ratio of primary production) & & & & & 0.003 & 0.079 & 0.004 & 0.11 \\
\hline pphy & exudation (ratio of primary production) & & & & & 0.003 & 0.079 & 0.004 & 0.11 \\
\hline
\end{tabular}


Table 3

Inequalities used for the computation of inverse analysis on the two sites, concerning annual data. All data are given in gC. $\mathrm{m}^{-2} . \mathrm{month}^{-1}$. All parameters are given, but references are mentioned only if they add to Leguerrier et al. (2003, 2004): (1) Altenbach, 1992, (2) Lagardère, 1987.

\begin{tabular}{cccccc}
\hline & & \multicolumn{2}{c}{ Aiguillon Cove } & \multicolumn{2}{c}{ Brouage Mudflat } \\
\hline compartment & parameter & minimum & maximum & minimum & maximum \\
\hline pmic & production & 0.062 & 0.864 & 0.04 & 0.56 \\
pmic & respiration & 0.102 & 0.646 & 0.066 & 0.418 \\
pmic & consommation & 0.246 & 5.39 & 0.159 & 3.49 \\
bfor & production ${ }^{(1)}$ & 0 & 1.225 & 0.186 & 5.13 \\
pmes & respiration & 0.033 & 0.149 & 0.02 & 0.092 \\
pmes & production & 0.017 & 0.443 & 0.01 & 0.271 \\
bnem & production & 0.066 & 4.43 & 0.204 & 3.6 \\
bnem & respiration & 0.303 & 15.51 & 0.728 & 2.62 \\
bbiv & respiration & 0.005 & 20.30 & 0.058 & 1.79 \\
bgas & production & 0 & 1.2 & 0.027 & 0.587 \\
bgas & respiration & 0 & 1.65 & 0.023 & 0.889 \\
bann & production & 0.0004 & 0.938 & 0.032 & 0.352 \\
bann & respiration & 0.0005 & 1.29 & 0.013 & 0.486 \\
bart & production & 0 & 0.443 & 0.034 & 0.304 \\
bart & respiration & 0 & 0.427 & 0.128 & 0.233 \\
bjuv & ingestion ${ }^{(2)}$ & 0.0002 & 0.038 & 0 & 1.084 \\
pphy & net & primary production & 1.14 & 2.86 & seasonal values (table 2) \\
\hline
\end{tabular}


Table 4

Result of inverse analysis computation for Aiguillon Cove and Brouage Mudflat physical fluxes (inputs, outputs, deposition and resuspension). FROM = compartment of origin; TO = destination compartment; $\mathrm{N}^{\circ}=$ flow number as in Figure 3. See Table 1 for abbreviations; $\mathrm{GPP}=$ Gross Primary Production; resp $=$ respiration. Fluxes in gC. $\mathrm{m}^{-2} \cdot \mathrm{month}^{-1}$. Flow values completely determined by equations are in bold.

\begin{tabular}{|c|c|c|c|c|c|c|}
\hline \multicolumn{2}{|c|}{ Fluxes } & \multirow[b]{2}{*}{$\mathrm{N}^{\circ}$} & \multicolumn{2}{|c|}{ Aiguillon Cove } & \multicolumn{2}{|c|}{ Brouage Mudflat } \\
\hline FROM & TO & & Summer & Winter & Summer & Winter \\
\hline river & pphy & 1 & 2.85 & 1.03 & 0 & 0 \\
\hline river & pmic & 2 & 0 & 4.65 & 0 & 0 \\
\hline river & pmes & 3 & 0 & 0 & 0 & 0 \\
\hline river & pdet & 4 & 5.23 & 7.09 & 0 & 0 \\
\hline ocean & pphy & 5 & 20.10 & 7.41 & 28.68 & 15.67 \\
\hline ocean & pmic & 6 & 0 & 4.65 & 1.21 & 0.27 \\
\hline ocean & pmes & 7 & 0 & 0 & 4.52 & 0 \\
\hline ocean & pdet & 8 & 194.08 & 144.76 & 283.24 & 381.14 \\
\hline pphy & export & 9 & 24.87 & 15.36 & 28.31 & 16.98 \\
\hline pmic & export & 10 & 8.13 & 0 & 1.97 & 0 \\
\hline pmes & export & 11 & 0.71 & 0.07 & 4.93 & 0.08 \\
\hline pdet & export & 12 & 85.08 & 74.63 & 243.58 & 303.85 \\
\hline bdet & burial & 13 & 31.96 & 29.01 & 11.83 & 44.01 \\
\hline bphy & pphy & 14 & 1.74 & 6.52 & 1.09 & 7.04 \\
\hline bdet & pdet & 15 & 0 & 0 & 42.55 & 4.99 \\
\hline pphy & bphy & 16 & 0 & 0 & 2.36 & 6.08 \\
\hline pdet & bdet & 17 & 53.11 & 45.62 & 31.17 & 23.24 \\
\hline cult & export & 18 & 0.02 & 0.05 & 0 & 4.03 \\
\hline pjuv & export & 19 & 0.01 & 0.01 & 0.23 & 0.11 \\
\hline bmul & export & 20 & 7.03 & 5.98 & 0.47 & 2.75 \\
\hline $\operatorname{limi}$ & export & 21 & 0.01 & 0.01 & 0.03 & 0.09 \\
\hline GPP & pphy & 22 & 0.80 & 0.56 & 1.93 & 0.52 \\
\hline GPP & bphy & 23 & 38.06 & 30.55 & 42.99 & 33.77 \\
\hline pphy & resp & 91 & 0.04 & 0.03 & 0.10 & 0.03 \\
\hline bphy & resp & 92 & 10.44 & 8.77 & 11.30 & 9.57 \\
\hline pmic & resp & 93 & 1.11 & 0 & 0.72 & 0 \\
\hline bfor & resp & 94 & 8.19 & 7.14 & 5.65 & 4.34 \\
\hline pmes & resp & 95 & 0.25 & 0.02 & 0.14 & 0.02 \\
\hline bnem & resp & 96 & 6.17 & 5.95 & 0.13 & 6.11 \\
\hline bbiv & resp & 97 & 1.84 & 0.43 & 3.02 & 0.08 \\
\hline bgas & resp & 98 & 0.91 & 0.53 & 0.44 & 1.52 \\
\hline bann & resp & 99 & 3.98 & 3.72 & 0.53 & 0.42 \\
\hline bart & resp & 100 & 3.13 & 2.05 & 0.15 & 0.35 \\
\hline cult & resp & 101 & 0.15 & 0.09 & 2.60 & 1.17 \\
\hline pjuv & resp & 102 & 0.02 & 0.01 & 0.38 & 0.18 \\
\hline bmul & resp & 103 & 9.43 & 7.81 & 0.79 & 3.37 \\
\hline limi & resp & 104 & 0.01 & 0.02 & 0.05 & 0.15 \\
\hline pdet & resp & 105 & 38.07 & 33.40 & 29.93 & 17.63 \\
\hline bdet & resp & 106 & 14.30 & 12.98 & 14.13 & 16.18 \\
\hline
\end{tabular}


Table 5

Numerical results of inverse analysis for the Aiguillon Cove and the Brouage Mudflat food web models. Flow noted as Flow FROM a TO b = biological exchanges between compartments a and b (flow in gC.m ${ }^{-2}$.month ${ }^{-1}$ ). Flows expressed in percentage of the total consumption by each consumer appeared in the diet of the consumer column (ratio in \%). See Table 1 for abbreviations and figure 2 for flow numbers $\left(\mathrm{N}^{\circ}\right)$. No flow value is in bold as no flow was directly determined by equations. The following null flows have been omitted for clarity: pphy To pphy (24), pmic To pphy (25), pmic To pmes (31), pmes To pmes (32), pphy To bbiv (38), pmic To bbiv (39), bfor To bbiv (42), bphy To bart (51), bnem To bart (53), bann To bart (56), pphy To cult (59), pmic To cult (60), bnem To pjuv (62), bann To pjuv (65) and bfor To bmul (68).

\begin{tabular}{|c|c|c|c|c|c|c|c|c|c|c|}
\hline & & & \multicolumn{4}{|c|}{ Flow value (gC.m ${ }^{-2}$.month $\left.{ }^{-1}\right)$} & \multicolumn{4}{|c|}{ Diet of the consumer (\%) } \\
\hline \multicolumn{3}{|c|}{ Flow } & \multicolumn{2}{|c|}{ Aiguillon Cove } & \multicolumn{2}{|c|}{ Brouage Mudflat } & \multicolumn{2}{|c|}{ Aiguillon Cove } & \multicolumn{2}{|c|}{ Brouage Mudflat } \\
\hline FROM & TO & $\mathrm{N}^{\circ}$ & Summer & Winter & Summer & Winter & Summer & Winter & Summer & Winter \\
\hline pdet & pmic & 26 & 9.24 & 0 & 3.35 & 0 & 100 & 0 & 100 & 0 \\
\hline bphy & bfor & 27 & 7.51 & 6.25 & 5.6 & 2.87 & 70 & 70 & 49 & 47 \\
\hline bdet & bfor & 29 & 3.22 & 2.68 & 5.44 & 1.25 & 30 & 30 & 47 & 21 \\
\hline pphy & pmes & 30 & 0.56 & 0.16 & 0.87 & 0.17 & 31 & 100 & 78 & 100 \\
\hline pdet & pmes & 33 & 1.22 & 0 & 0.25 & 0 & 69 & 0 & 22 & 0 \\
\hline bphy & bnem & 34 & 0 & 0 & 13.7 & 13.53 & 0 & 0 & 70 & 55 \\
\hline bfor & bnem & 35 & 0 & 0 & 0.13 & 0 & 0 & 0 & 1 & 0 \\
\hline bnem & bnem & 36 & 0 & 0 & 0.94 & 1.34 & 0 & 0 & 5 & 5 \\
\hline bdet & bnem & 37 & 13.34 & 11.89 & 4.94 & 9.82 & 100 & 100 & 25 & 40 \\
\hline pdet & bbiv & 40 & 12.07 & 6.07 & 7.94 & 0.92 & 70 & 70 & 64 & 63 \\
\hline bphy & bbiv & 41 & 1.5 & 0 & 0 & 0 & 9 & 0 & 0 & 0 \\
\hline bdet & bbiv & 43 & 3.67 & 2.6 & 4.56 & 0.53 & 21 & 30 & 36 & 37 \\
\hline bphy & bgas & 44 & 1.3 & 0.76 & 1.09 & 0.86 & 100 & 100 & 20 & 22 \\
\hline bdet & bgas & 45 & 0 & 0 & 4.4 & 3.06 & 0 & 0 & 80 & 78 \\
\hline bphy & bann & 46 & 1.77 & 1.64 & 0 & 0 & 29 & 29 & 0 & 0 \\
\hline bfor & bann & 47 & 0.84 & 0.69 & 0 & 0 & 14 & 12 & 0 & 0 \\
\hline bnem & bann & 48 & 1.64 & 1.47 & 1.39 & 0.48 & 27 & 26 & 48 & 69 \\
\hline bann & bann & 49 & 0.56 & 0.66 & 0.6 & 0 & 9 & 12 & 21 & 0 \\
\hline bdet & bann & 50 & 1.27 & 1.18 & 0.89 & 0.22 & 21 & 21 & 31 & 31 \\
\hline bfor & bart & 52 & 0.52 & 0.34 & 0 & 0 & 10 & 10 & 0 & 0 \\
\hline bbiv & bart & 54 & 1.54 & 1 & 0.49 & 0.53 & 30 & 30 & 32 & 52 \\
\hline bgas & bart & 55 & 0.18 & 0 & 0.3 & 0.34 & 3 & 0 & 19 & 33 \\
\hline bart & bart & 57 & 0.44 & 0.44 & 0.31 & 0.01 & 8 & 13 & 20 & 1 \\
\hline bdet & bart & 58 & 2.5 & 1.6 & 0.45 & 0.14 & 48 & 47 & 29 & 14 \\
\hline pdet & cult & 61 & 1.32 & 1.57 & 12.66 & 40.3 & 100 & 100 & 100 & 100 \\
\hline bbiv & pjuv & 63 & 0.05 & 0.02 & 0.38 & 0.27 & 100 & 100 & 49 & 77 \\
\hline bgas & pjuv & 64 & 0 & 0 & 0.19 & 0.08 & 0 & 0 & 25 & 23 \\
\hline bart & pjuv & 66 & 0 & 0 & 0.2 & 0 & 0 & 0 & 26 & 0 \\
\hline bphy & bmul & 67 & 11.99 & 9.14 & 1.58 & 1.58 & 51 & 46 & 100 & 17 \\
\hline bnem & bmul & 69 & 0 & 0 & 0 & 3.56 & 0 & 0 & 0 & 39 \\
\hline bdet & bmul & 70 & 11.45 & 10.81 & 0 & 4.02 & 49 & 54 & 0 & 44 \\
\hline bbiv & limi & 71 & 0.0085 & 0.0237 & 0.1 & 0.24 & 55 & 59 & 100 & 83 \\
\hline bgas & $\operatorname{limi}$ & 72 & 0.0031 & 0.0074 & 0 & 0.05 & 20 & 18 & 0 & 17 \\
\hline bann & limi & 73 & 0.0031 & 0.0074 & 0 & 0 & 20 & 18 & 0 & 0 \\
\hline bart & $\operatorname{limi}$ & 74 & 0.0008 & 0.0018 & 0 & 0 & 5 & 4 & 0 & 0 \\
\hline pdet & pdet & 75 & 42.3 & 37.11 & 33.25 & 19.59 & & & & \\
\hline pphy & pdet & 77 & 0 & 0 & 0.04 & 0.01 & & & & \\
\hline bdet & bdet & 76 & 15.89 & 14.43 & 58.42 & 62.74 & & & & \\
\hline bphy & bdet & 78 & 0 & 0 & 10.78 & 4.7 & & & & \\
\hline pmic & pdet & 79 & 0 & 9.31 & 1.88 & 0.28 & & & & \\
\hline bfor & bdet & 80 & 1.07 & 0.89 & 4.68 & 0.61 & & & & \\
\hline pmes & pdet & 81 & 0.83 & 0.08 & 0.56 & 0.09 & & & & \\
\hline bnem & bdet & 82 & 5.34 & 4.76 & 17.34 & 13.07 & & & & \\
\hline bbiv & bdet & 83 & 13.68 & 7.37 & 8.07 & 0.94 & & & & \\
\hline bgas & bdet & 84 & 0.26 & 0.15 & 4.5 & 2 & & & & \\
\hline bann & bdet & 85 & 1.47 & 1.37 & 1.8 & 0.2 & & & & \\
\hline bart & bdet & 86 & 1.54 & 1 & 0.96 & 0.57 & & & & \\
\hline cult & bdet & 87 & 0.35 & 2.55 & 8.78 & 36.87 & & & & \\
\hline pjuv & pdet & 88 & 0.01 & 0.0045 & 0.15 & 0.07 & & & & \\
\hline bmul & bdet & 89 & 6.98 & 6.15 & 0.32 & 3.04 & & & & \\
\hline limi & bdet & 90 & 0.003 & 0.01 & 0.02 & 0.06 & & & & \\
\hline
\end{tabular}


Table 6

Sum of fluxes from inverse analysis computations for Aiguillon Cove and Brouage Mudflat models. Internal fluxes are fluxes between two compartments of the system; benthic and pelagic fluxes refer to the sink compartments. Fluxes in gC.m ${ }^{-2} \cdot$ month $^{-1}$ and ratio in \%.

\begin{tabular}{lcccc}
\hline & \multicolumn{2}{c}{ Aiguillon Cove } & \multicolumn{2}{c}{ Brouage Mudflat } \\
\hline \multicolumn{1}{c}{ Properties } & Summer & Winter & Summer & Winter \\
\hline Sum of all fluxes & 751 & 607 & 1026 & 1139 \\
Sum of internal benthic fluxes & 81 & 66 & 161 & 156 \\
$\begin{array}{l}\text { Sum of internal pelagic fluxes } \\
\text { Ratio of sum of detritivory fluxes to }\end{array}$ & 54 & 47 & 40 & 23 \\
sum of herbivory fluxes & 4.77 & 5.01 & 5.98 & 7.50 \\
\hline
\end{tabular}

